\title{
WestVirginiaUniversity
}

THE RESEARCH REPOSITORY @ WVU

Graduate Theses, Dissertations, and Problem Reports

2008

\section{Effects of cognitive processing and cell phone use while driving}

Michelle Leigh Sudhoff

West Virginia University

Follow this and additional works at: https://researchrepository.wvu.edu/etd

\section{Recommended Citation}

Sudhoff, Michelle Leigh, "Effects of cognitive processing and cell phone use while driving" (2008). Graduate Theses, Dissertations, and Problem Reports. 4425.

https://researchrepository.wvu.edu/etd/4425

This Thesis is protected by copyright and/or related rights. It has been brought to you by the The Research Repository @ WVU with permission from the rights-holder(s). You are free to use this Thesis in any way that is permitted by the copyright and related rights legislation that applies to your use. For other uses you must obtain permission from the rights-holder(s) directly, unless additional rights are indicated by a Creative Commons license in the record and/ or on the work itself. This Thesis has been accepted for inclusion in WVU Graduate Theses, Dissertations, and Problem Reports collection by an authorized administrator of The Research Repository @ WVU. For more information, please contact researchrepository@mail.wvu.edu. 


\title{
Effects of Cognitive Processing and Cell Phone Use While Driving
}

\author{
by \\ Michelle Leigh Sudhoff \\ Thesis submitted to the \\ College of Engineering and Mineral Resources \\ at West Virginia University \\ in partial fulfillment of the requirements \\ for the degree of \\ Master of Science \\ in \\ Industrial Engineering \\ Kevin Rider, Ph.D., Committee Chair \\ Rashpal Ahluwalia, Ph.D. \\ Gary Winn, Ph.D. \\ Department of Industrial \& Management Systems Engineering \\ Morgantown, West Virginia \\ 2008
}

Keywords: Cell Phone, Driving, Inattention Blindness, Distraction, Vehicle

Copyright 2008 Michelle L. Sudhoff 


\section{ABSTRACT \\ Michelle Leigh Sudhoff \\ Effects of Cognitive Processing and Cell Phone Use While Driving}

With 233 million cell phone subscribers in the United States at the end of the year 2006, and $73 \%$ of those subscribers talking on their cell phones while driving, the issue of safety on the roads has become a major one. While there has been widespread research on the causes of driver distraction, and comparisons among those causes, there has not been research conducted in order to evaluate the effects of visual imagery on driver performance. This research employed two types of programs to examine the response time to the presented stimuli, as well as missed targets among 16 subjects. For each program, subjects completed six tasks (Baseline, Mental Arithmetic, Directions, Synonyms, In Person Conversation, Cell Phone Conversation). In the stimulus-response program, subjects were asked to press certain keys on a keyboard, corresponding to the stimuli presented on the screen (The six trials in this program included simple response of space bar upon stimulus; selecting a, s, d, or f; selecting a, s, d, f, j, or k; selecting a, s, d, f, j, k, l, or “;”; selecting a, s, d, or f with "a" 75\% more likely; selecting a, d, j, or k incompatible). In the driving video program, subjects were asked to press " $r$ " or "w" when a red or white/silver car as soon as they perceived a car of that color to be approaching in the opposite lane. Upon analysis of the stimulus-response program, it was found that Task and Trial Type were significant, with three of the tasks (cell phone conversation, in-person conversation, and synonyms) were highly significantly different from the directions and mental arithmetic tasks. Upon analysis of the driving video program, it was found that Task was a significant factor for missed targets. In conclusion, it was found that tasks involving mental imagery were significantly different than tasks requiring simple communication. 


\section{ACKNOWLEDGEMENTS}

I would like to thank several people who have been key elements to the completion of this paper. This has been quite a journey and I feel blessed to have such wonderful people supporting me as I have traveled through it.

I would like to thank Dr. Kevin Rider, my thesis advisor, friend, and life mentor. My experience as a graduate student would not have been the same without his insight into many matters. I feel that I had a rewarding graduate experience, and am honored to have worked with him. I am amazed at his commitment to his students, and making sure they achieve all of their goals. He has become a friend that I will keep in contact with for many years.

My thesis committee deserves my utmost thanks for aiding me in this process. Dr. Gary Winn and Dr. Rashpal Ahluwalia have been excellent mentors, even during my undergraduate time at West Virginia University. It has been a wonderful experience dealing with both professors for both my undergraduate and graduate stint.

I would also like to thank my friend and mentor Amie Heath for her support through the many stages of thesis writing. She has been a wonderful comfort to speak with about frustrations of deadlines, problems, and life issues. Without her encouragement, I would have felt hopeless on several occasions. She also provided the driving video for use in my thesis.

I would like to thank Matt Sines, a close family friend, for developing the driving video program. Without this program I would not have completed my thesis. He has been a wonderfully patient friend who I am forever grateful for.

Most importantly, I would like to thank my family. My parents, Fred and Shirley, who have watched me grow from a small child into an engineer with a promising future ahead of her. They have made so much of my education possible, and have always been there for me when I needed them. I cannot say how much they have done for me in my lifetime. I am blessed to have such amazing and supportive parents.

A special thanks to my husband, Carl, for his daily support, encouragement, and patience as I have traveled this road. He has performed many roles as I have worked through this process, including cheerleader, cook, housemaid, caretaker, and most of all, a loving husband. I appreciate all he has done for me. 


\section{TABLE OF CONTENTS}

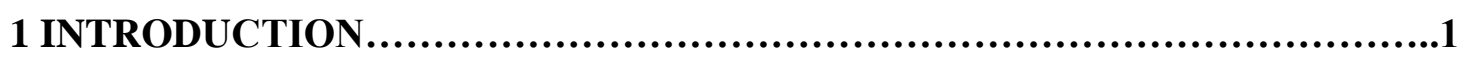

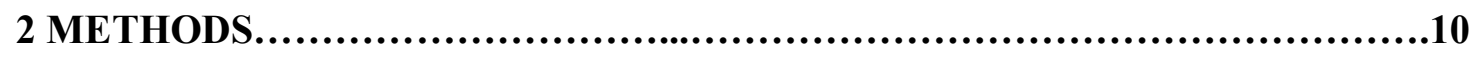

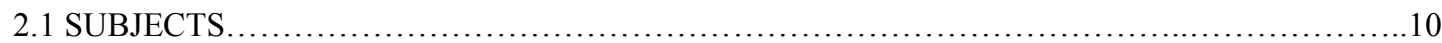

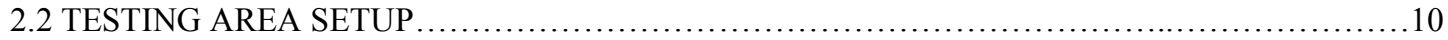

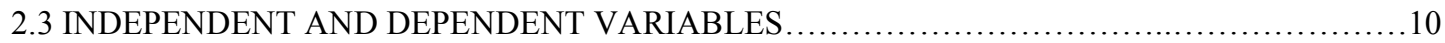

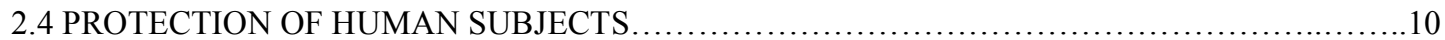

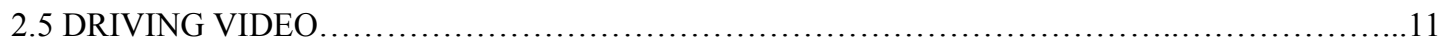

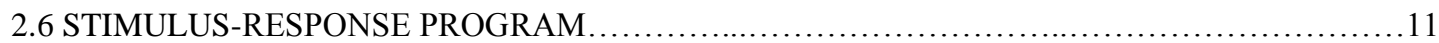

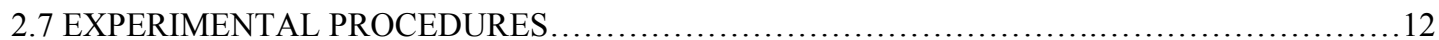

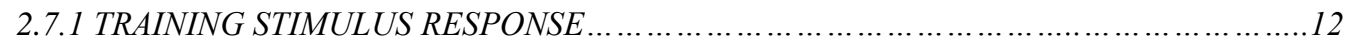

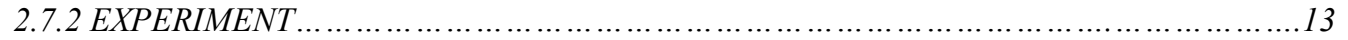

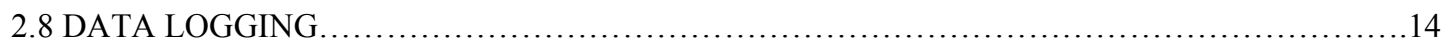

3 PRELIMINARY RESULTS..............................................15

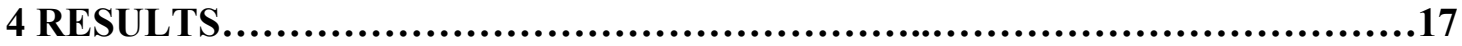

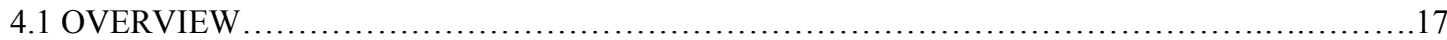

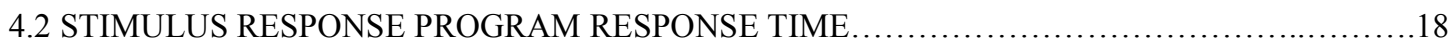

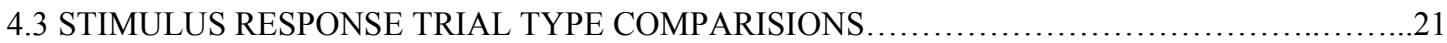

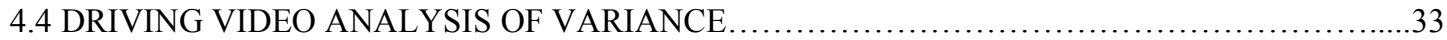

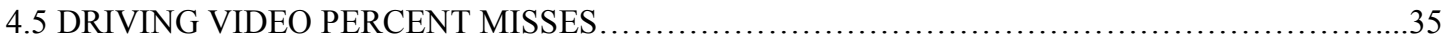

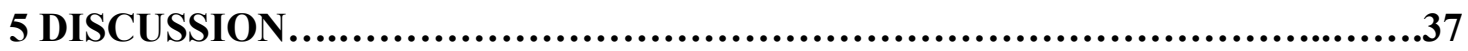

REFERENCES.........................................................................43

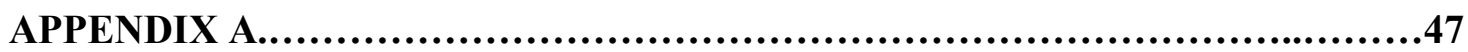




\section{LIST OF TABLES}

TABLE 1 - TASKS AND TRIALS THAT EACH SUBJECT COMPLETED ............................13

TABLE 2 - BREAKDOWN OF ORDER IN WHICH SUBJECTS COMPLETED TWO PROGRAMS...14

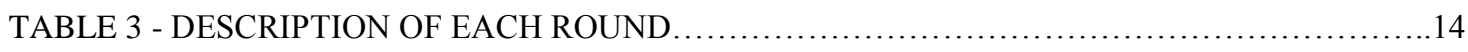

TABLE 4 - INFORMATION THEORY PRELIMINARY RESULTS ..................................

TABLE 5 - ANALYSIS OF VARIANCE FOR THE STIMULUS-RESPONSE PROGRAM................17

TABLE 6 - ANALYSIS OF VARIANCE FOR THE DRIVING VIDEO PROGRAM......................18

TABLE 7 - AVERAGE RESPONSE TIMES FOR EACH AGE GROUP FOR EACH TASK................19

TABLE 8 - AVERAGE RESPONSE TIMES FOR GENDER FOR EACH TASK ….......................19

TABLE 9 - NUMERICAL CODE USED FOR TASKS IN MINITAB ...................................2

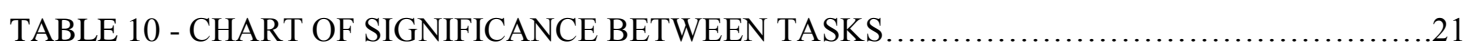

TABLE 11 - AVERAGE RESPONSE TIMES FOR EACH TASK .........................................

TABLE 12 - TRIAL TYPE DESCRIPTIONS FOR THE STIMULUS-RESPONSE PROGRAM............22

TABLE 13 - CHART OF SIGNIFICANCE FOR THE BASELINE TASK TRIAL TYPES...................22

TABLE 14 - RESPONSE TIMES FOR EACH TRIAL TYPE IN THE BASELINE TASK..................22

TABLE 15 - CHART OF SIGNIFICANCE FOR MENTAL ARITHMETIC TASK TRIAL TYPES.......23

TABLE 16 - RESPONSE TIMES FOR EACH TRIAL TYPE IN THE MENTAL ARITHMETIC

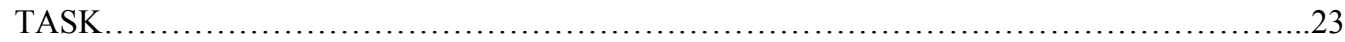

TABLE 17 - CHART OF SIGNIFICANCE FOR DIRECTIONS TASK TRIAL TYPES ...................23

TABLE 18 - RESPONSE TIMES FOR EACH TRIAL TYPE IN THE DIRECTIONS TASK...............24

TABLE 19 - CHART OF SIGNIFICANE FOR SYNONYMS TASK TRIAL TYPES......................24

TABLE 20 - RESPONSE TIMES FOR EACH TRIAL TYPE IN THE SYNONYMS TASK................24

TABLE 21 - CHART OF SIGNIFICANCE FOR EACH TRIAL TYPE IN THE IN PERSON

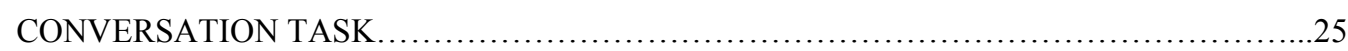

TABLE 22 - RESPONSE TIMES FOR EACH TRIAL TYPE IN THE IN PERSON CONVERSATION

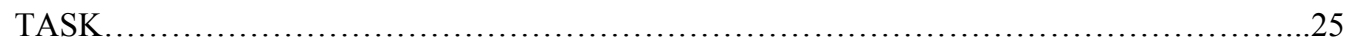

TABLE 23 - CHART OF SIGNIFICANCE FOR CELL PHONE CONVERSATION TASK TRIAL

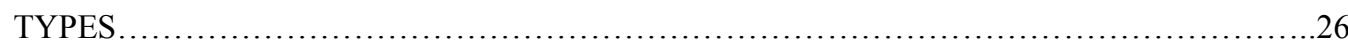

TABLE 24 - RESPONSE TIMES FOR EACH TRIAL TYPE IN THE CELL PHONE CONVERSATION

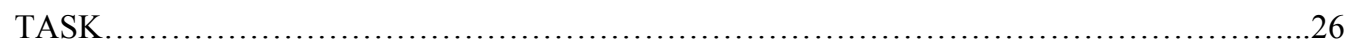




\section{LIST OF FIGURES}

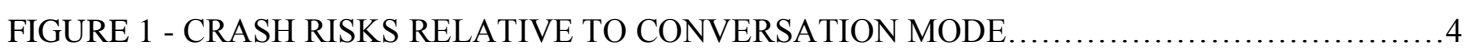

FIGURE 2 - THREE DIMENSIONS OF ATTENTIONAL RESOURCES...............................

FIGURE 3 - COMPARISION TESTS BETWEEN AGE GROUPS....................................2

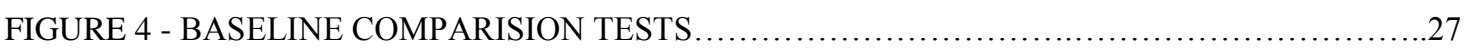

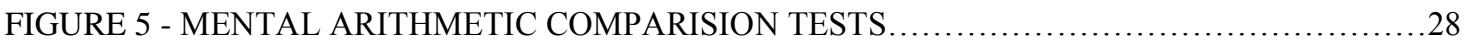

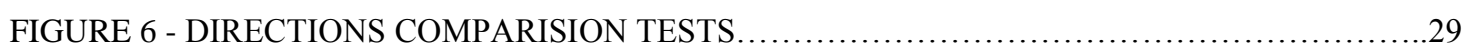

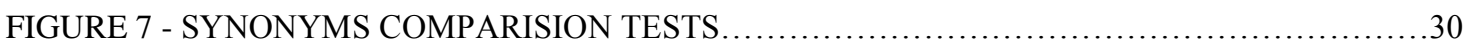

FIGURE 8 - IN PERSON CONVERSATION COMPARISION TESTS...................................

FIGURE 9 - CELL PHONE CONVERSATION COMPARISION TESTS ..................................

FIGURE 10 - MULTIPLE COMPARISION TEST FOR TASKS .....................................

FIGURE 11 - MAXIMUM CONSECUTIVE MISSES PER TASK AND AVERAGE MISSES PER TASK .35

FIGURE 12 - MAXIMUM CONSECUTIVE MISSES PER TASK AND AVERAGE MISSES PER TASK, AFTER ELIMINATION OF OUTLIERS. . .36 


\section{INTRODUCTION}

Cellular telephones are increasingly prevalent throughout the United States, and their use while driving has become an increasing hazard to unacceptable levels. According to the Cellular Telecommunications Industry Association (CTIA) there were approximately 233 million cell phone subscribers at the end of the year 2006. It has been estimated that $73 \%$ of those subscribers talk on their cell phones while driving (Nationwide Mutual Insurance, Co, 2007). Nationwide Insurance (2007) also reported that $35 \%$ of Generation $Y$ (ages 16-30), 30\% of Generation X (ages 31-45) and 21\% of baby boomers (ages 46-60) admit to multitasking in the car while driving.

Since 1987, the average length of cellular telephone calls has increased from 2.33 minutes per call to 3.03 minutes per call (CTIA, 2007), thereby increasing the risk of an accident due to prolonged durations of divided attention. It has also been found that the length of phone calls may create poor driving task performance. During a recent study it was found that drivers executing shorter phone calls had a tendency to reduce their speed, while drivers executing longer phone calls typically increased their average speed (Rosenbloom, 2006). This study also found that maintaining a safe distance from the lead car did not appear to change due to the length of the phone call.

The Insurance Information Institute (2007) found that $80 \%$ of crashes (as well as $65 \%$ of near-crashes) "involved some form of driver inattention within three seconds of the event". Seo and Torabi (2004) completed a study in which $21 \%$ of the accidents or near-accidents included in the study involved at least one driver using a cell phone, most commonly the cell phone was being used for conversation. The Insurance Advocate (2000) reported that a Farmers Insurance Group survey concluded that more than $40 \%$ of adults "reported having had close calls or near hits with a driver who was on the phone." In 2001, the San Diego Business Journal reported that the Response Insurance National Driving Habits Survey concluded that $76 \%$ of drivers engage in distracting activities, with $29 \%$ of drivers talking on the phone while driving. Of those $29 \%$, it was reported that $13 \%$ of the drivers felt it caused, or almost caused, an accident (Katz, 2001).

Although some argue that more experienced cell phone users can manage the dual task situation, experienced cell phone users have been shown to have an increased risk for an accident (Heath \& Rider, 2007; Redelmeier \& Tibshirani, 1997). Redelmeier and 
Tibshirani (1997) also found that risk of collision while using a cell phone were very similar for groups of different age, gender, job, driving experience, and cell phone experience. The authors did note that drivers who had not graduated from high school did have a slightly higher risk (Redelmeier \& Tibshirani, 1997).

Many studies suggest that most of the problems related to the driver distraction caused by cell phones are due to the cognitive processing of independent requirements of multiple tasks (i.e. divided attention), and are commonly associated with increased reaction times (Horrey \& Wickens, 2006; Consiglio et al., 2003; Wood \& Hurwitz, 2005; Strayer \& Drews, 2004; Alm \& Nilsson, 1995; Tornros \& Bolling, 2005; Beede \& Kass, 2005). Irwin et al. (2000) found the braking response time to be increased by up to $24 \%$, requiring as much as 25 additional feet to stop from $60 \mathrm{mph}$ ( 7.5 meters at $96.5 \mathrm{kph}$ ). These two studies compared the two variables of reaction time and response time; often the definitions of each are blurred. According to Microsoft Encarta, reaction time is defined as "the interval of time between the application of the stimulus and the first indication of a response" (Reaction Time, 2007), while response time is the amount of time to do something "in reaction to something else" (Response, 2007). Response and reaction times are only two variables of driving that can be affected by the distraction of cell phones; others include variability in speed, headway between cars, and lane deviation. Other sources of distraction for drivers include listening to the radio, navigation systems, vehicle controls, and other passengers.

Horrey and Wickens (2006) investigated the effects of driving while conversing on a cell phone, and found that the largest performance costs were related primarily to reaction time tasks, though decreases in tracking task performance was also significant. Consiglio, et al. (2003) supports this finding with data suggesting that phone use can cause reaction time to slow by up to $19 \%$. Horrey and Wickens (2006) also stated that generally conversation tasks impaired driving performance more than informationprocessing tasks, thus suggesting active conversation leads to the distraction, and not the processing of information received.

According to The National Automotive Sampling System, "driver inattention was a driver-related pre-crash factor in about 26\% of all sampled crashes for 1995" (NHTSA, 2008). With the increasing probability of accidents that can be associated with driver 
distraction, lawmakers have begun to limit cell phone use on the roads. Legislation has been enacted in Connecticut, New York, New Jersey, and the District of Columbia prohibiting driving while talking on a handheld phone, but has not banned all cell phone use while driving (Governors Highway Safety Association, 2007). While this may be a step in the right direction, studies show that even hands-free cell phones can be dangerous. McEvoy et al. (2005) found that the use of a cell phone "up to 10 minutes before the estimated time of the crash was associated with a fourfold increase in the likelihood of crashing (odds ratio $4.1,95 \%$ confidence interval 2.2 to $7.7, \mathrm{P}<0.001$ )". It was also shown that there are "significant associations between mobile phone use and the likelihood of a crash" (McEvoy, et al., 2005). The research completed by McEvoy, et al. (2005) suggests that gender, age, and the mobile device does not control the probability of vehicle accidents.

Strayer, Drews, and Crouch (2006) found that driving while using a cell phone (handheld or hands-free) can cause similar safety risks as driving while under the influence of alcohol. It was shown that "when drivers were conversing on a cell phone, they were involved in more rear-end collisions and took longer to recover the speed that they had lost during braking than when they were intoxicated". It was also shown that there "were significantly more accidents when subjects were conversing on a cell phone than in the baseline or alcohol conditions" (Strayer, et al., 2006), thus suggesting that driving while talking on a cell phone can be even more dangerous than driving under the influence of alcohol. Redelmeier \& Tibshirani (1997) also support this by posturing that the relative risk of an accident while talking on a cell phone is similar to that of driving while under the influence of alcohol.

While the profiles of the two types of drivers (those on cell phones and those intoxicated) differ in driving styles, both appear to be a threat to road safety. One other important factor analyzed in this study was the role of experience in combining cell phone use with driving. It was found that practice, such as using a cell phone while driving many times, does not result in enhanced driving performance. (Strayer, et al., 2006)

It also has been argued that remote conversations are different from passenger conversations because passengers may be able to modulate the conversation based on the 
driving scene (Esbjornsson and Juhlin, 2003). In a recent study, Hunton and Rose (2005) have shown that incidents increased with cell phone conversations when compared to passenger conversations. It is important to note that incidents were also higher when any type of conversation was present than no conversation at all.

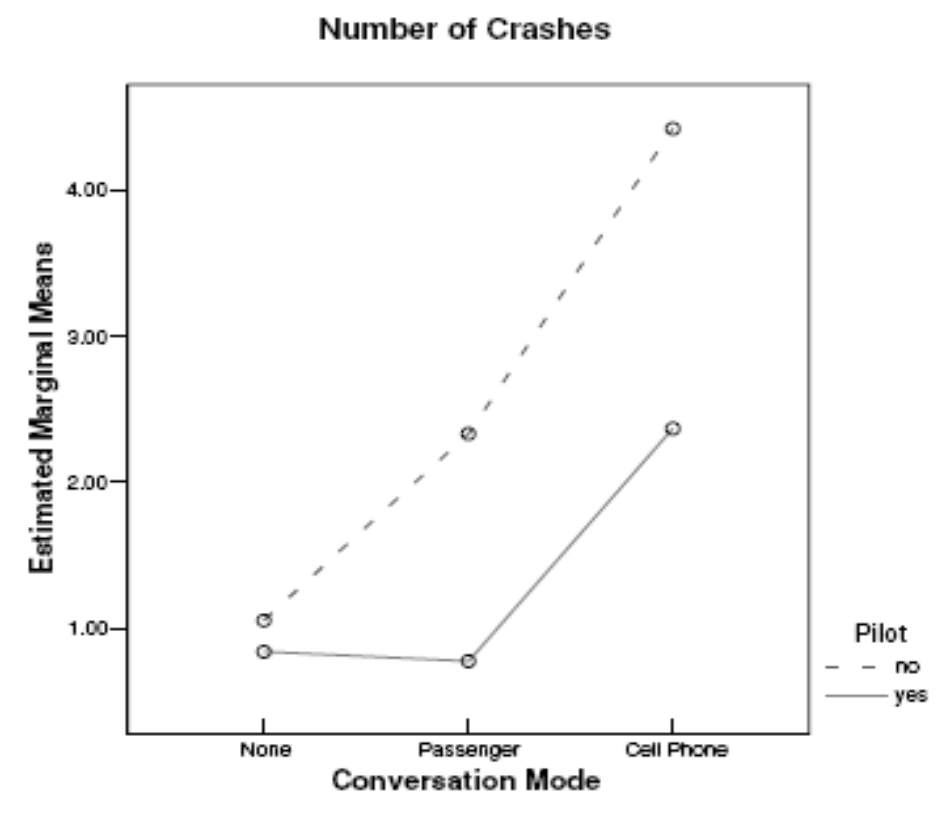

Figure 1 - Crash risks relative to conversation mode (Hunton \& Rose, 2005).

Talking on a cell phone while driving may not be the only driver distraction of concern, one study found that driving performance decrements were only slightly different between cell phone conversations and passenger conversations (Consiglio et al, 2003). However the authors admit that in reality there are differences between cell phone conversations and passenger conversations, specifically the pace of the conversations.

Gugerty, Rakauskas, and Brooks (2004) investigated this difference and found that teams, comprised of one member performing a simulated driving task, interacted slower verbally with the remote conversations than with in-person conversations, suggesting that it is more difficult to converse remotely. The mean verbalization rate showed that the conversations were $15 \%$ slower with remote conversations than with inperson conversations (Gugerty et al, 2004).

In a recent study it was determined that hands-free and handheld phones are very similar in the amount of increased workload caused by phone use (Tornros \& Bolling, 
2005). This study found no difference between either phone mode when dealing with dialing and lateral position deviation. It has also been shown that hands-free and handheld phones can create equally distracting effects (Consiglio, et al., 2003).

Strayer, Drews, and Johnston (2003) suggest that it is the cell phone conversation, and not the cell phone type, that distracts the attention of the driver from the external environment to an engaging internal environment associated with the conversation. During one of the experiments in this study, it was shown that driving performance was impaired when subjects were conversing on a hands-free cell phone, with the impairment becoming more pronounced during simulated high-density traffic situations (Strayer, et al., 2003). This suggests that the cell phone conversation diverted attention away from the driving scene.

To support this conjecture, Strayer, Drews, and Johnston (2003) performed an experiment in which subjects performed a simulated driving task and were exposed to several billboards in the driving scene, and then subsequently were tested on their recall of these billboards. It was shown that "even when the participants eyes were directed at objects in the driving environment, they were less likely to remember them if they were conversing on a cell phone" (Strayer, et al, 2003). The inattention to the driving scene is supported in a similar study involving eye tracking. McCarley, et al. (2001) have shown that in dual-task situations, eye movements were more frequent when attempting to detect scene differences. This suggests that conversation can "impair peripheral guidance of attention toward the target" (McCarley, et al., 2001).

Lamble, et al (1999) conducted a study in which headway to a lead car and timeto-collision situations were examined. In this study it was found that "drivers' detection ability in a closing headway situation was impaired by about $0.5 \mathrm{sec}$ in terms of brake reaction time and almost $1 \mathrm{sec}$ in terms of time-to-collision, when they were doing a nonvisual cognitive task whilst driving" (Lamble, et. al, 1999). These two detection times were slightly slower times than when drivers were performing a visual attention task.

Divided attention is commonly fit into the model of multiple resource theory, developed by Christopher Wickens (Boles \& Law, 1998). The model was “constructed on the basis of a review of studies assessing interference between different pairs of tasks, and it models resources in terms of three dimensions". The three dimensions are as 
follows: stages of processing, modality, and processing code. This model suggests that divided attention among multiple tasks is a function of overlap between the resources needed for that task (Boles \& Law, 1998).

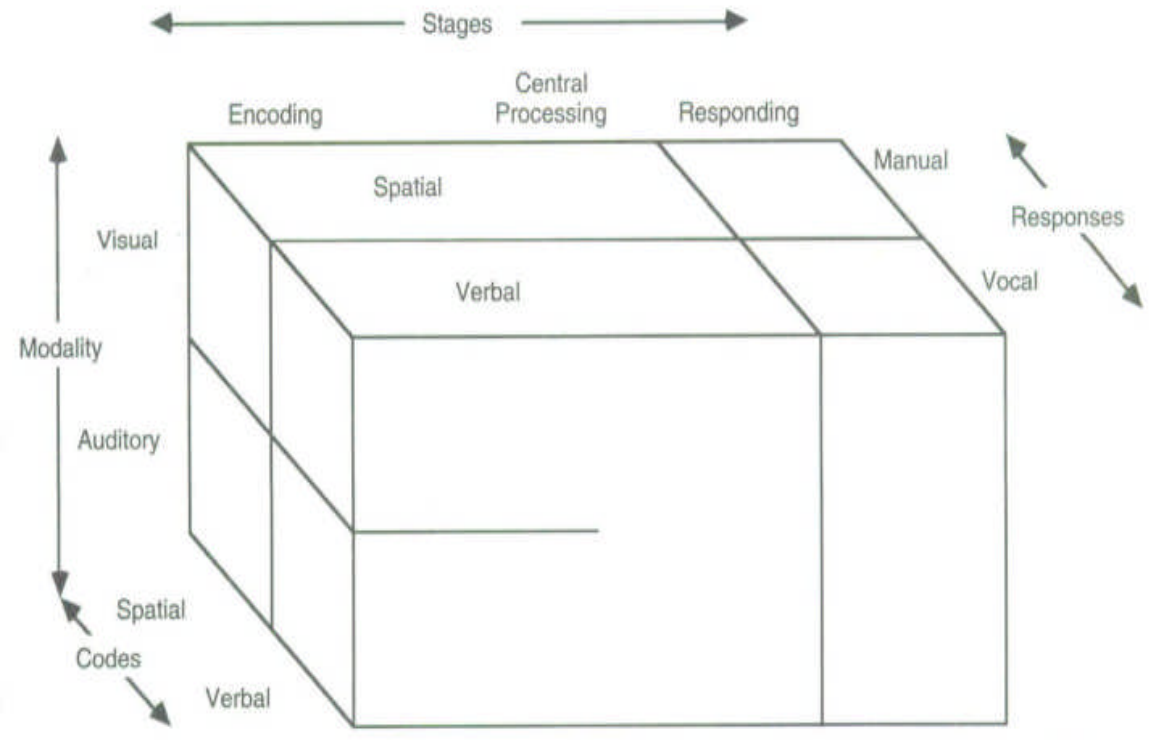

Figure 2 - Three dimensions of attentional resources (Smith \& Buchholz, 1991)

Divided attention can affect cognitive workload. Brookhuis, De Vries, and De Waard (1991) found that as demands of a task increase, heart rate and heart rate variability also increase. Thus, when a telephone task was performed, heart rate increased. This research is supported by another study that also suggests driving while conversing on a cell phone causes an increase in heart rate during the phone call (Haigney, et al, 2000). It was found that the mean heart rate was highest during the phone call time period, and that this effect was present when both hands-free and handheld cell phones were used. The author suggests that "participants were finding task performance cognitively more effortful in the during call period, and were having to invest greater attentional resources in task performance" (Haigney, et al, 2000).

Matthews, Legg, and Charlton (2003) compared cognitive workload between handheld, hands-free, and personal hands-free phones. Their study suggests that personal hands-free phones, such as a phone with a Bluetooth connection, had the lowest total subjective workload. It was also found that all phones had similar mental and temporal demand. 
Amado and Ulupmar (2005) conducted a study to compare the effects of passenger conversations and remote conversations on attention and peripheral detection. In this study, it was found that any type of conversation was more distracting than omitting conversation, and that there was not a significant difference between passenger conversations and remote conversations. It is important to note that the subjects performing the tests were not licensed drivers, and the conversations were not natural conversations, instead they were direct questions with very short responses.

Some research suggests that divided attention, and the stress it puts on cognitive workload, may differ among personality types. Baker and Madell (1965) conducted an experiment where 24 male college students were identified as underachievers or achievers, and then were given reading comprehension tests under two conditions. The first condition was a quiet setting, while the second condition included the auditory distraction of humorous conversation. It was found that under the first condition, underachievers and achievers performed statistically the same. The second condition caused distraction for both groups of subjects, however the underachievers had a performance decrement of $51 \%$ while the performance decrement for achievers was only 25\% (Baker \& Madell, 1965).

There is also research on divided attention and it's affect on people with a Type A or Type B personality. Typically, “Type A behavior is characterized by extreme competitiveness, achievement striving, time urgency, hostility, and aggressiveness...Type B behavior is defined as the more moderate display of these descriptive features" (Glass et. al., 1980). Glass et. al (1980) conducted a study in which subjects were determined to have either a Type A or Type B behavior pattern by a structured interview process. After determination of personality type, subjects then participated in a tracking task. A second task was presented in which subjects were asked to repeat a number previous to the current number stated. For example, if the experimenter began with the number 4 , followed by the number 7 , a correct response from the subject would be "4". In half of the trials of the study, the experimenters also introduced an environmental stressor of white noise. It was found that "reliably greater elevations in systolic blood pressure and plasma E were noted for Type A's compared to 
Type B's" (Glass et. al., 1980). These results suggest greater stress responses when confronted by task overload for those with a Type A personality (Glass et. al, 1980).

Personality types may also be characterized as neurotic, extravert, and introvert (Belojevic, Jakovljevic, and Slepcevic, 2003). Belojevic, Jakovljevic, and Slepcevic (2003) state that "Neuroticism is often thought to be reflected in self-oriented thoughts, worry and anxiety, each of which act as a distracter from learning and recall". It is also suggested that extroverts are highly alert, and typically are very aware of their surroundings. In this study, the authors examined differences in adaptation to noise over a twelve-year period for persons of different personalities. It was found that extroverts tend to adapt to noise distractions during a mental task (Belojevic, Jakovljevic, and Slepcevic, 2003).

Huguet et. al. (1999) suggest that social presence (audiences) effect performance on the Stroop task. The Stroop task is a fairly popular experiment and has been the subject of many experiments in the past. The idea behind the Stroop task is that subjects are asked to determine the ink color a word is written in. Most often, the time needed to identify the ink color for incongruent words is larger than that of congruent words. For example, the time need to identify the ink color of the word RED would take longer than the time to identify the ink color of the word GREEN (Huguet et. al., 1999).

In Huguet et al's study (1999), subjects performed the Stroop task with different "types" of audiences present. In this study, subjects completed the Stroop task under varying conditions. Subjects performed the task alone and with differing audiences, and some tasks required memory recognition. The results of this study found that Stroop interference (the difference in identifying the correct ink color for incongruent and congruent words) was decreased when subjects had an unpredictable audience. It was also found that when Stroop interference decreased, so did the recognition memory of the words used (Huguet et. al, 1999).

Szymura and Necka (1998) compared visual selective attention and personality to assess selectivity, distraction susceptibility, sustained attention, and dual task performance. The authors predicted that extraverts would commit fewer errors if the task was difficult and proved mental stimulation, that extraverts would be more impulsive and commit more false alarms in detection tasks, and that extraverts will have shorter 
response latencies in dual task situations. All of the authors' predictions were confirmed, except that extraverts would respond more quickly in the more difficult version of the attention task (Szymura \& Necka, 1998).

Eysenck and Graydon (1989) examined how personality may effect attentional distraction. Twelve subjects were identified as either stable extroverts or neurotic introverts based on an EPI (Eysenck Personality Inventory) scale. It was found that there was "significant effect of distracting conditions on the neurotic introvert group" (Eysenck \& Graydon, 1989).

There is a significant amount of research that has been conducted by governments, insurance companies, and scholars on the distractions that cell phone use poses to the primary task of driving. Much of the relevant research investigates if cell phone use is an equal distraction to other commonly occurring events, such as changing radio stations, conversing with a passenger, or even driving under the influence of alcohol.

It is hypothesized that subjects' reaction times will be significantly longer when distracted by secondary tasks such as cell phone conversation, mental arithmetic, giving directions to common locations, and memory recall tasks. It is also hypothesized that subjects will not respond at all to some stimuli when performing tasks that may require mental imagery, such as giving directions, due to the cognitive distraction. 


\section{METHODS}

\subsection{Subjects}

This study included 16 subjects, 8 male and 8 female. All participation was voluntary. The age range for the subjects was 23-50 years. The average age was 31.92 years. This age range was chosen due to the aforementioned statistics regarding multitasking while driving, and includes ages in Generation Y and Generation X. All subjects possessed valid driver's licenses, owned \& used a cell phone, and had normal or corrected to normal vision.

\subsection{Testing Area Setup}

The experiment was conducted at any convenient location for each subject. Subjects sat in front of a laptop computer, at a comfortable distance away from the screen. A blank poster board surrounded the computer in order to prevent unintentional distractions during testing.

\subsection{Independent and Dependent Variables}

The independent variables for this study were distractions posed to the subject such as a cell phone conversation, in-person conversation, mental arithmetic, synonyms, and giving directions. The dependent variables in this study were reaction time and percent misses.

\subsection{Protection of Human Subjects}

Prior to testing, subjects were briefed on the nature of the study and procedures. Following this briefing, subjects were asked to sign a consent form (Appendix A). The consent form acknowledged the nature of the study, procedure, researcher information, benefits of the study, and any potential risks associated with the study. The only 
potential discomfort subjects faced in this study was sitting in front of a computer screen for a short duration of time.

\subsection{Driving Video}

Prior to testing, a thirty-minute driving video was created. The driving video was created for use in Heath \& Rider's (2007) previous work. The video shows the driving scene from the driver's perspective, in which the subject was able to see the steering wheel, dashboard, rearview mirror, and the windshield. The video included in-town driving scenes (stoplights \& intersections). After discovering a slight learning affect with the first subject watching the same video clip for all six rounds, the driving video was divided into three four-minute sections. Subjects 2-5 completed trials 1 and 4 while watching the first four-minute section, trials 2 and 5 while watching the second fourminute section, and trials 3 and 6 while watching the third four-minute section. Subjects 6-10 completed trials 1 and 4 while watching the third four-minute section, trials 2 and 5 while watching the first four-minute section, and trials 3 and 6 while watching the second four-minute section. Finally, subjects 11-16 completed trials 1 and 4 while watching the second four-minute section, trials 2 and 5 while watching the third four-minute section, and trials 3 and 6 while watching the first four-minute section.

Subjects were asked to press the "r" key when a red vehicle was first perceived to be red, or the "w" key when a white/silver vehicle was first perceived to be white or silver. In order for vehicle to be considered, the vehicle must be established on the road and moving in the opposite direction. Keystrokes were recorded and time-stamped in order to compare hits and misses of the stimulus. There were a total of 53 red vehicles and 110 white/silver vehicles to be identified.

\subsection{Stimulus-Response Program}

Prior to testing, a short program was obtained from Professor Michael Lewis' (University of Pittsburgh) online syllabus (2008). The program has six different trials in which the following occur in successive order: stimulus is presented requiring the spacebar to be pressed, one of four letters ( $a, s, d, f)$ are presented randomly requiring the 
corresponding letter to be pressed, one of six letters (a, s, d, f, j, k) are presented randomly requiring the corresponding letter to be pressed, one of eight symbols ( $\mathrm{a}, \mathrm{s}, \mathrm{d}, \mathrm{f}$, $\mathrm{j}, \mathrm{k}, 1, ;$ )are presented randomly requiring the corresponding symbol to be pressed, one of four letters (a, s, d, f) are presented with the likelihood of "a" being displayed to be $75 \%$ requiring the corresponding letter to be pressed, and one of four letters $(a, d, j, k)$ are presented incompatibly and randomly requiring the corresponding letter to be pressed. The program recorded the stimulus, response, and time between stimulus and response.

\subsection{Experimental Procedures}

Upon entering the testing area, subjects were briefed on the nature of the study and completed the consent form. Subjects were then provided with an overview of the study, detailing the process involved. Subjects were informed that this study would take approximately 2.5 hours to complete, and only one visit would be required to complete the study. Half of the subjects began with the driving video portion, while the other half began with the stimulus-response program. During the first 30 minutes of the stimulusresponse portion, subjects were asked to complete 4 training trials of the program to account for the learning curve. Following the training trials, subjects spent approximately 50 minutes participating in the stimulus-response program. During the first 4 minutes of the driving video portion, subjects were asked to complete 1 training trial of 4 minutes to account for the learning curve. Subjects then spent approximately 25 minutes participating in the driving scene analysis.

Subject numbers were assigned to subjects as they were able to participate in the experiment. For example, the third person to complete the experiment was "Subject 3". Subjects were briefed on the distractions that took place during the experiment. Following the experiment, subjects completed a perception survey.

\subsubsection{Training Subjects}

Prior to completing the tasks assigned, subjects were asked to familiarize themselves with the stimulus-response computer program. During this section of the experiment, subjects sat in front of the computer and placed their hands on the keyboard. Subjects then completed trials 1-6 for a total of 4 times to eliminate any effect of the 
learning curve in the actual experiment. Prior to commencement of the entire experiment, the number of training trials required to eliminate this effect were determined to be 4 times.

Subjects also completed one four-minute trial of the driving video analysis to eliminate any effect of the learning curve. The subjects were asked to identify red and white/silver vehicles in a different four-minute clip than the ones presented in the experiment.

\subsubsection{Experiment}

Subjects were asked to complete six rounds (with six trials each for the stimulusresponse program, as demonstrated in Table 1) on two computer programs, the stimulusresponse program as well as recording hits and misses for the driving video scene analysis. Eight of the subjects (four male and four female) completed the driving video program first, followed by the stimulus-response program. The remaining eight subjects (four male and four female) completed the stimulus-response program first, followed by the driving video program, as seen in Table 2. The six rounds were the same for both programs and subjects completed them in the same predetermined order, and are described in Table 3. The predetermined order for subjects was randomized.

Table 2 - Tasks and trials that each subject completed.

\begin{tabular}{|c|c|c|c|c|c|c|c|}
\hline & \multicolumn{6}{|c|}{ Task } \\
\hline & & Baseline & $\begin{array}{c}\text { Mental } \\
\text { Arithmetic }\end{array}$ & Directions & Synonyms & \begin{tabular}{|c|} 
In-Person \\
Conv.
\end{tabular} & $\begin{array}{c}\text { Cell Phone } \\
\text { Con. }\end{array}$ \\
\hline \multirow{6}{*}{$\frac{\vec{J}}{\mathbb{\Phi}}$} & Spacebar & $x$ & $x$ & $x$ & $x$ & $x$ & $x$ \\
\hline & $a, s, d, f$ & $x$ & $x$ & $x$ & $x$ & $x$ & $x$ \\
\hline & $a, s, d, f, j, k$ & $x$ & $x$ & $x$ & $x$ & $x$ & $\mathrm{x}$ \\
\hline & $a, \mathbf{s}, d, \mathbf{f}, \mathbf{j}, \mathbf{k}, \mathrm{l}$, ; & $x$ & $x$ & $\mathrm{x}$ & $x$ & $\mathrm{x}$ & $\mathrm{x}$ \\
\hline & $a, s, d, f$, "a" 75\% likely & $x$ & $x$ & $x$ & $x$ & $x$ & $x$ \\
\hline & a, d, j, k, incompatible & $x$ & $x$ & $x$ & $x$ & $x$ & $x$ \\
\hline
\end{tabular}


Table 2 - Breakdown of order in which subjects complete two programs.

\begin{tabular}{|c|c|c|c|}
\hline Subject & Gender & Part One & Part Two \\
\hline 1FSR & Female & Stimulus-Response & Driving Video \\
\hline 2FSR & Female & Stimulus-Response & Driving Video \\
\hline 3FDV & Female & Driving Video & Stimulus-Response \\
\hline 4FDV & Female & Driving Video & Stimulus-Response \\
\hline 5FSR & Female & Stimulus-Response & Driving Video \\
\hline 6FSR & Female & Stimulus-Response & Driving Video \\
\hline 7FDV & Female & Driving Video & Stimulus-Response \\
\hline 8FDV & Female & Driving Video & Stimulus-Response \\
\hline 1MSR & Male & Stimulus-Response & Driving Video \\
\hline 2MSR & Male & Stimulus-Response & Driving Video \\
\hline 3MDV & Male & Driving Video & Stimulus-Response \\
\hline 4MDV & Male & Driving Video & Stimulus-Response \\
\hline $5 \mathrm{MSR}$ & Male & Stimulus-Response & Driving Video \\
\hline $6 \mathrm{MSR}$ & Male & Stimulus-Response & Driving Video \\
\hline 7MDV & Male & Driving Video & Stimulus-Response \\
\hline 8MDV & Male & Driving Video & Stimulus-Response \\
\hline
\end{tabular}

Table 3 - Description of each round

\begin{tabular}{|c|c|}
\hline Round & Description \\
\hline Mental Artithmetic & $\begin{array}{c}\text { Asked to answer predetermined mental arithmetic questions, } \\
\text { asked every } 15 \text { seconds. }\end{array}$ \\
\hline In-Person Conversation & Subject is engaged in casual conversation by the experimenter \\
\hline Cell Phone Conversation & Subject is asked to carry a cell phone conversation \\
\hline Directions & $\begin{array}{c}\text { Subject is given a location and a destination and is asked to give } \\
\text { driving directions to experimenter }\end{array}$ \\
\hline Synonyms & $\begin{array}{r}\text { Subjects are given a word and are asked to answer with a } \\
\text { synonym, words are presented every 15 seconds. }\end{array}$ \\
\hline Baseline & Subject completes trials without any distraction. \\
\hline
\end{tabular}

\subsection{Data Logging}

For the driving video portions of the experiment, keystrokes were recorded along with a timestamp. The driving video stimuli were previously time stamped, allowing for comparison of hits and misses for each subject. All data was recorded in a text file.

For the stimulus-response program, the stimulus, response, and time between stimulus and response were recorded in a text file. 


\section{PRELIMINARY RESULTS}

Prior to commencing the experiment, a preliminary testing sequence was completed. It was found that completing the stimulus-response task while talking on a cell phone produced statistically significant $(\alpha=0.05)$ increased average response times for three trials (simple response time, selection among four choices, and incompatible selection among four choices) when compared to a baseline. Two trials (selection among 8 choices and selection among four choices with "a" being 75\% likely) were not found to be significant at a level of $\alpha=0.05$, but had p-values of 0.084 and 0.0628 , respectively.

It was also found that conversing in-person also produced statically significant ( $\alpha$ $=0.05$ ) increased average response times for two trials (simple response time and selection among four choices) when compared to a baseline. One trial (selection among four choices with "a" being 75\% likely) was not found to be significant at a level of $\alpha$ $=0.05$, but had a $\mathrm{p}$-value of 0.1188 .

Average response times for the cell phone distraction and in-person distraction were also compared. It was found that in tasks perceived as more difficult, talking on a cell phone produced increased average response times. Two trials (selection among 8 choices and selection among four incompatible choices) produced highly significant ( $\mathrm{p}=$ 0.03) results, suggesting that although either distraction negatively affects performance, conversing on a cell phone during difficult tasks is much more distracting.

One of the most interesting preliminary results involves the task in which the subject gives driving directions for various locations. All trials produced highly significant $(\alpha=0.02)$ increased average response times. This could be due to the visual cortex processing the detailed directions.

Other distractions such as answering mental arithmetic questions, memory-recall tasks, and determining synonyms for common words also produced significant $(\alpha=0.05)$ results in several different trials. For the experiment underhand, it was determined that the memory-recall tasks resembled the synonym task enough to use only the synonym task due to time limitations.

Responses were also compared to the stimulus presented to analyze information transmission. The results were evaluated for information transmitted, noise, and equivocation. The results are listed below in Table 4 . 
Table 4 - Information Theory Preliminary Results

\begin{tabular}{|c|c|c|c|c|c|c|}
\hline Task & Trial & Info Sent & Info Received & Info Transmitted & Noise & Equivocation \\
\hline \multirow{5}{*}{ Baseline } & 2 & 1.90 & 1.90 & 1.90 & 0.00 & 0.00 \\
\hline & 3 & 2.42 & 2.24 & 2.24 & 0.00 & 0.18 \\
\hline & 4 & 2.85 & 2.71 & 2.71 & 0.00 & 0.14 \\
\hline & 5 & 1.05 & 1.32 & 1.05 & 0.27 & 0.00 \\
\hline & 7 & 1.96 & 1.97 & 1.17 & 0.80 & 0.79 \\
\hline \multirow{5}{*}{ Cell Phone } & 2 & 1.94 & 1.90 & 1.72 & 0.18 & 0.22 \\
\hline & 3 & 2.25 & 1.91 & 1.40 & 0.52 & 0.85 \\
\hline & 4 & 2.88 & 2.88 & 2.88 & 0.00 & 0.00 \\
\hline & 5 & 1.15 & 1.32 & 1.05 & 0.27 & 0.10 \\
\hline & 7 & 1.94 & 1.98 & 1.77 & 0.21 & 0.17 \\
\hline \multirow{5}{*}{ In-Person } & 2 & 1.96 & 1.92 & 1.74 & 0.18 & 0.22 \\
\hline & 3 & 2.55 & 2.41 & 3.01 & 0.46 & 0.60 \\
\hline & 4 & 2.63 & 2.56 & 2.42 & 0.14 & 0.21 \\
\hline & 5 & 1.32 & 1.44 & 1.18 & 0.26 & 0.14 \\
\hline & 7 & 1.94 & 1.99 & 1.78 & 0.21 & 0.16 \\
\hline \multirow{5}{*}{ Directions } & 2 & 1.94 & 1.93 & 1.54 & 0.39 & 0.40 \\
\hline & 3 & 2.41 & 2.41 & 2.41 & 0.00 & 0.00 \\
\hline & 4 & 2.77 & 2.77 & 2.77 & 0.00 & 0.00 \\
\hline & 5 & 0.99 & 0.99 & 0.56 & 0.43 & 0.43 \\
\hline & 7 & 1.88 & 1.93 & 1.55 & 0.38 & 0.33 \\
\hline \multirow{5}{*}{ Memory Recall } & 2 & 1.60 & 1.60 & 1.60 & 0.00 & 0.00 \\
\hline & 3 & 2.49 & 2.49 & 2.17 & 0.32 & 0.32 \\
\hline & 4 & 2.71 & 2.71 & 2.71 & 0.00 & 0.00 \\
\hline & 5 & 0.85 & 0.75 & 0.75 & 0.00 & 0.10 \\
\hline & 7 & 1.96 & 1.90 & 1.58 & 0.32 & 0.38 \\
\hline \multirow{5}{*}{ Synonyms } & 2 & 1.81 & 1.85 & 1.62 & 0.23 & 0.20 \\
\hline & 3 & 2.43 & 2.33 & 2.19 & 0.14 & 0.24 \\
\hline & 4 & 2.73 & 2.73 & 2.73 & 0.00 & 0.00 \\
\hline & 5 & 1.48 & 1.36 & 1.22 & 0.14 & 0.26 \\
\hline & 7 & 1.96 & 1.95 & 1.58 & 0.37 & 0.38 \\
\hline \multirow{5}{*}{ Radio } & 2 & 1.81 & 1.81 & 1.81 & 0.00 & 0.00 \\
\hline & 3 & 2.50 & 2.55 & 2.37 & 0.18 & 0.14 \\
\hline & 4 & 2.75 & 2.61 & 2.61 & 0.00 & 0.14 \\
\hline & 5 & 0.99 & 0.99 & 0.99 & 0.00 & 0.00 \\
\hline & 7 & 1.90 & 1.93 & 1.57 & 0.36 & 0.33 \\
\hline \multirow{5}{*}{ Mental Math } & 2 & 1.77 & 1.77 & 1.77 & 0.00 & 0.00 \\
\hline & 3 & 2.47 & 2.32 & 1.82 & 0.50 & 0.65 \\
\hline & 4 & 2.50 & 2.23 & 1.73 & 0.50 & 0.78 \\
\hline & 5 & 0.47 & 0.61 & 0.33 & 0.28 & 0.14 \\
\hline & 7 & 1.99 & 2.00 & 1.44 & 0.56 & 0.54 \\
\hline
\end{tabular}




\section{RESULTS}

\subsection{Overview}

After collection of data, an analysis of variance (ANOVA) was performed. For this experiment, $\mathrm{p}$-values of less than 0.01 were considered highly significant while values between 0.05 and 0.01 were considered significant. The response variable used in the stimulus-response program was "Response Time". The results of the ANOVA are listed in Table 5. It was found that task, trial type, age (grouped into three categories: 2130, 31-40, and 41-50), gender, the interaction between age and gender, the interaction between age and task, and the interaction between age, gender, and task were all significant. A Tukey multiple comparison test revealed that the Baseline task was highly significantly different from the Mental Arithmetic task and the Directions task (p-values of 0.0000). Also, the Mental Arithmetic task was found to be highly significantly different than the Synonyms task, In Person Conversation, and Cell Phone Conversation, with p-values of 0.0000 . The Directions task was highly significantly different from the Synonyms task, In Person Conversation, and the Cell Phone Conversation (p-values of $0.0001,0.0000$, and 0.0000 respectively) as well. It was also found that the Baseline task was not significantly different than the Synonyms task, In Person Conversation, or Cell Phone Conversation.

Table 5 - Analysis of Variance for the Stimulus-Response Program

\begin{tabular}{|c|c|c|c|c|c|c|}
\hline Source & DF & Seq SS & Adj SS & Adj MS & $\mathbf{F}$ & $\mathbf{P}$ \\
\hline Task & 5 & 27.2571 & 16.1666 & 3.2333 & 30.45 & $0.000^{\star *}$ \\
\hline SR Trial & 5 & 22.7910 & 20.0266 & 4.0053 & 37.72 & $0.000^{* *}$ \\
\hline Age & 2 & 2.5927 & 0.7587 & 0.3793 & 3.57 & $0.029^{\star \star *}$ \\
\hline Gender & 1 & 5.1438 & 3.4267 & 3.4267 & 32.27 & $0.000^{* *}$ \\
\hline Task*SR Trial & 25 & 0.8830 & 0.8697 & 0.0348 & 0.33 & 0.999 \\
\hline Task ${ }^{*}$ Age & 10 & 3.6460 & 3.8554 & 0.3855 & 3.63 & $0.000^{* *}$ \\
\hline Task*Gender & 5 & 1.4563 & 0.9750 & 0.1950 & 1.84 & 0.105 \\
\hline SR Trial*Age & 10 & 2.0410 & 1.0922 & 0.1092 & 1.03 & 0.419 \\
\hline SR Trial ${ }^{*}$ Gender & 5 & 0.7263 & 0.8327 & 0.1665 & 1.57 & 0.168 \\
\hline Age ${ }^{*}$ Gender & 2 & 5.7335 & 5.7335 & 2.8667 & 27.00 & $0.000^{\star \star}$ \\
\hline Task*SR Trial*Age & 50 & 2.5681 & 1.8626 & 0.0373 & 0.35 & 1.000 \\
\hline Task $^{\star}$ SR Trial ${ }^{*}$ Gender & 25 & 0.7895 & 1.0689 & 0.0428 & 0.40 & 0.996 \\
\hline Task*Age*Gender & 10 & 4.3314 & 4.3314 & 0.4331 & 4.08 & $0.000^{\star \star}$ \\
\hline SR Trial ${ }^{\star} \mathrm{Age}^{\star}$ Gender & 10 & 1.4169 & 1.4169 & 0.1417 & 1.33 & 0.210 \\
\hline Task $^{\star}$ SR Trial ${ }^{\star}$ Age $^{*}$ Gender & 50 & 1.5079 & 1.5079 & 0.0302 & 0.28 & 1.000 \\
\hline Error & 360 & 38.2282 & 38.2282 & 0.1062 & & \\
\hline
\end{tabular}


It was found that the only factor to be significant was Task in the driving video program, using "Percent Misses" as a response variable. Following (Table 6) are the results of the analysis of variance.

Table 6 - Analysis of Variance for the Driving Video Program

\begin{tabular}{|l|c|c|c|c|c|c|}
\hline Source & DF & Seq SS & Adj SS & Adj MS & F & P \\
\hline Task & 5 & 0.72504 & 0.69151 & 0.13830 & 2.37 & $0.05^{\star *}$ \\
\hline Age & 2 & 0.00114 & 0.00114 & 0.00057 & 0.01 & 0.99 \\
\hline Gender & 1 & 0.14533 & 0.11976 & 0.11976 & 2.05 & 0.16 \\
\hline Task $^{*}$ Age & 10 & 0.18130 & 0.14958 & 0.01496 & 0.26 & 0.99 \\
\hline Task $^{\star}$ Gender & 5 & 0.12820 & 0.10372 & 0.02074 & 0.36 & 0.88 \\
\hline Age $^{\star} G e n d e r$ & 2 & 0.01099 & 0.01099 & 0.00549 & 0.09 & 0.91 \\
\hline Task^Age $^{\star}$ Gender & 10 & 0.09446 & 0.09446 & 0.00945 & 0.16 & 1.00 \\
\hline Error & 54 & 3.15019 & 3.15019 & 0.05834 & & \\
\hline
\end{tabular}

\subsection{Stimulus-Response Program Response Time}

It was found that task, trial type, age, gender, the interaction between age and gender, the interaction between age and task, and the interaction between age, gender, and task were all significant factors.

Age was found to be a significant factor in the ANOVA, and a Tukey multiple comparison test was performed in order to discover which age groups differed significantly from another. The results show that the age group 21-30 was significantly different (p-value of 0.0298) than the age group of 41-50. The results are shown in Figure 3. Table 7 displays the average response times for each age group for each task. Gender was also found to be significant. The comparison of response times is listed in Table 8. 
Table 7 - Average response times for each age group for each task.

\begin{tabular}{|c|c|c|}
\hline \multirow{3}{*}{ Task } & Age & $\begin{array}{c}\text { Average } \\
\text { RT }\end{array}$ \\
\hline \multirow{3}{*}{ Baseline } & $21-30$ & 0.7131 \\
\cline { 2 - 3 } & $31-40$ & 0.8092 \\
\cline { 2 - 3 } & $41-50$ & 1.1045 \\
\hline \multirow{3}{*}{$\begin{array}{c}\text { Mental } \\
\text { Arithmetic }\end{array}$} & $21-30$ & 1.4972 \\
\cline { 2 - 3 } & $31-40$ & 1.3694 \\
\cline { 2 - 3 } Directions & $41-50$ & 1.2683 \\
\cline { 2 - 3 } & $21-30$ & 1.1104 \\
\cline { 2 - 3 } & $31-40$ & 1.3249 \\
\hline \multirow{3}{*}{ Synonyms } & $41-50$ & 1.2921 \\
\cline { 2 - 3 } & $21-30$ & 0.9178 \\
\cline { 2 - 3 } & $31-40$ & 0.9626 \\
\hline \multirow{3}{*}{ In Person } & $41-50$ & 1.1572 \\
\cline { 2 - 3 } Conversation & $21-30$ & 0.7775 \\
\cline { 2 - 3 } & $31-40$ & 0.8874 \\
\hline \multirow{2}{*}{$\begin{array}{c}\text { Cell Phone } \\
\text { Conversation }\end{array}$} & $41-50$ & 0.9964 \\
\cline { 2 - 3 } & $21-30$ & 0.8398 \\
\hline \multirow{3}{*}{} & $31-40$ & 0.8872 \\
\hline
\end{tabular}

Table 8 - Average response times for gender for each task.

\begin{tabular}{|c|c|c|c|}
\hline Task & Gender & Average RT & Difference \\
\hline \multirow{2}{*}{ Baseline } & M & 0.7066 & \multirow{2}{*}{0.2078} \\
\hline & $\mathrm{F}$ & 0.9144 & \\
\hline \multirow{2}{*}{$\begin{array}{c}\text { Mental } \\
\text { Arithmetic }\end{array}$} & $M$ & 1.2646 & \multirow{2}{*}{0.3156} \\
\hline & $\mathrm{F}$ & 1.5802 & \\
\hline \multirow{2}{*}{ Directions } & M & 1.1595 & \multirow{2}{*}{0.0772} \\
\hline & $\mathrm{F}$ & 1.2367 & \\
\hline \multirow{2}{*}{ Synonyms } & $\mathrm{M}$ & 0.8196 & \multirow{2}{*}{0.3086} \\
\hline & $\mathrm{F}$ & 1.1282 & \\
\hline \multirow{2}{*}{$\begin{array}{c}\text { In Person } \\
\text { Convasation }\end{array}$} & $M$ & 0.7822 & \multirow{2}{*}{0.1277} \\
\hline & $\mathrm{F}$ & 0.9099 & \\
\hline \multirow{2}{*}{$\begin{array}{l}\text { Cell Phone } \\
\text { Conversation }\end{array}$} & $M$ & 0.7937 & \multirow{2}{*}{0.2142} \\
\hline & $\mathrm{F}$ & 1.0079 & \\
\hline
\end{tabular}




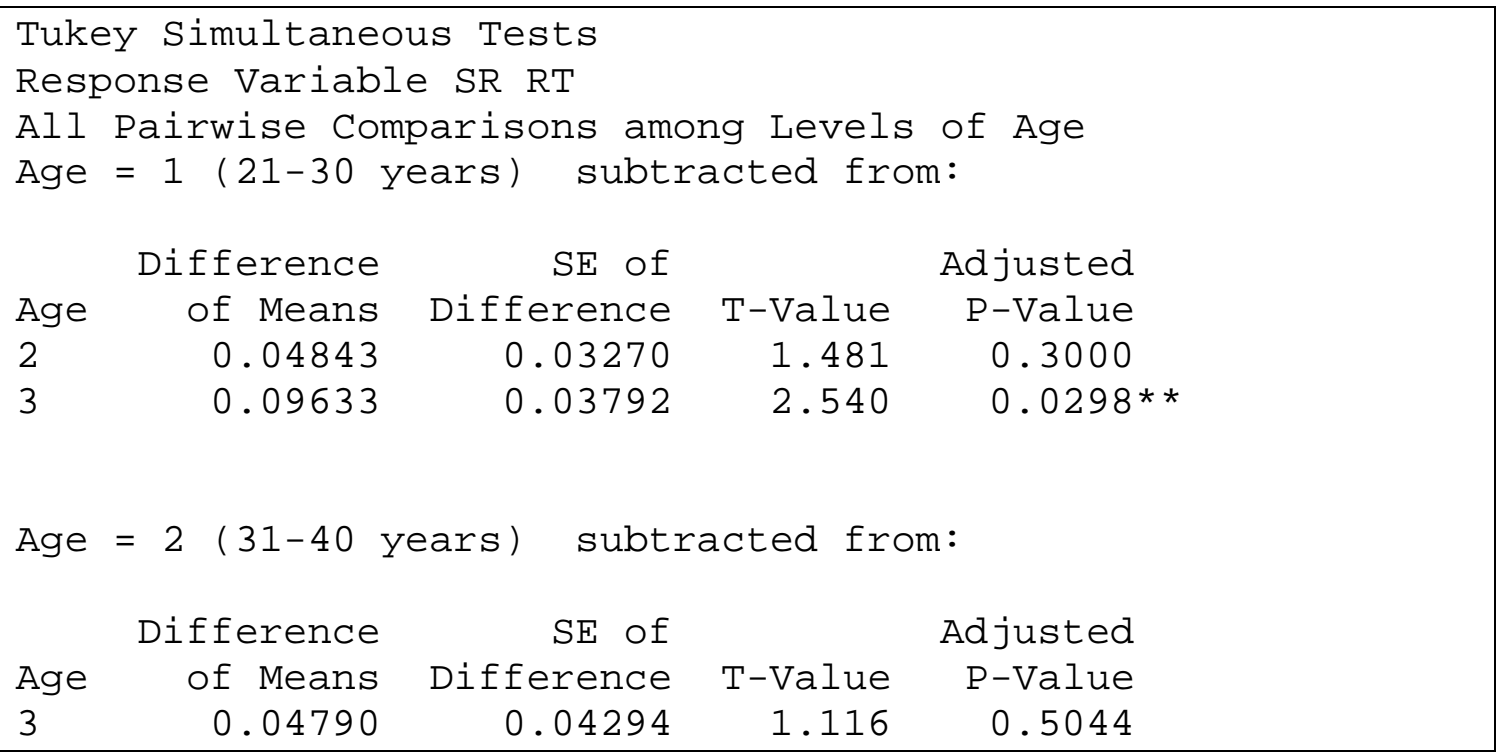

Figure 3 - Comparison tests between age groups.

Due to the fact that task was a highly significant factor in the ANOVA, a multiple comparison test (Tukey test) was performed in Minitab. The tasks were coded numerically for use in Minitab, and the descriptions are listed in Table 9.

Table 9 - Numerical Code Used for Tasks in Minitab

\begin{tabular}{|c|c|}
\hline Task & Description \\
\hline 1 & Baseline \\
\hline 2 & Mental Arithmetic \\
\hline 3 & Giving Directions \\
\hline 4 & Synonyms \\
\hline 5 & In Person Conversation \\
\hline 6 & Cell Phone Conversation \\
\hline
\end{tabular}

It was found that the baseline task was highly significantly $(\mathrm{p}<0.0001)$ different than the mental arithmetic task and the directions task. Also, the mental arithmetic task was found to be highly significantly different than the synonyms task, in person conversation, and cell phone conversation. As well as the directions task was highly significantly different from the synonyms task, in person conversation, and the cell phone conversation. A chart of significance (Table 10) was created to graphically compare tasks. Table 11 displays the average response times for each task. 
Table 10 - Chart of Signficance between Tasks

\begin{tabular}{|c|c|c|c|c|c|c|c|}
\hline & & \multicolumn{6}{|c|}{ Task } \\
\hline & & 1 & 2 & 3 & 4 & 5 & 6 \\
\hline \multirow{6}{*}{ Task } & 1 & & $x$ & $x$ & 0 & 0 & 0 \\
\hline & 2 & & & 0 & $x$ & $x$ & $x$ \\
\hline & 3 & & & & $\mathrm{x}$ & $x$ & $x$ \\
\hline & 4 & & & & & 0 & 0 \\
\hline & 5 & & & & & & 0 \\
\hline & 6 & & & & & & \\
\hline
\end{tabular}

Table 11 - Average response times for each task.

\begin{tabular}{|c|c|}
\hline Task & Average RT \\
\hline Baseline (1) & 0.8105 \\
\hline Mental Arithmetic (2) & 1.4224 \\
\hline Directions (3) & 1.1981 \\
\hline Synonyms (4) & 0.9739 \\
\hline In Person Convo (5) & 0.8460 \\
\hline Cell Convo (6) & 0.9008 \\
\hline
\end{tabular}

\subsection{Stimulus-Response Trial Type Comparisons}

The effects of task, trial type, age, and gender were examined using an analysis of variance (ANOVA) in the software program Minitab. Multiple comparisons were performed to determine which tasks and which trial types were significantly different from each other.

The stimulus-response program was broken into 6 trial types, with their descriptions listed in Table 12. P-values below 0.05 are considered "significant" while pvalues below 0.01 are considered to be highly significant. The trial types were compared using paired t-tests for each of the tasks the subject completed (baseline, mental arithmetic, giving directions, synonyms, in person conversation, and cell phone conversation). 
Table 12 - Trial Type Descriptions for the Stimulus-Response Program

\begin{tabular}{|c|c|}
\hline Trial Type Number & Description \\
\hline 1 & Press spacebar upon stimulus \\
\hline 2 & Press a, $\mathrm{s}, \mathrm{d}$, or $\mathrm{f}$ upon stimulus \\
\hline 3 & Press $\mathrm{a}, \mathrm{s}, \mathrm{d}, \mathrm{f}, \mathrm{j}$, or $\mathrm{k}$ upon stimulus \\
\hline 4 & Press a, $\mathrm{s}, \mathrm{d}, \mathrm{f}, \mathrm{j}, \mathrm{k}, \mathrm{l}$, or $;$ upon stimulus \\
\hline 5 & Press a, $\mathrm{s}, \mathrm{d}$, or $\mathrm{f}$ upon stimulus, with a $75 \%$ more likely to appear \\
\hline 6 & Press $\mathrm{a}, \mathrm{d}, \mathrm{j}$ or $\mathrm{k}$ upon stimulus, with incompatible order \\
\hline
\end{tabular}

After analyzing the stimulus-response results for the baseline task, it was found that trial type 1 was not significantly different than trial type 5 . Trial type 3 , type 4 , and type 6 all were highly significantly different than trial type 1. It was also found that trial type 4 was significantly different than trial type 5 with a p-value of 0.01 . In addition, it was found that trial type 5 was significantly different than trial type 6 with a p-value of 0.02 . Tables 13 and 14 display the results graphically as well as the response times related to each trial.

Table 13 - Chart of significance for the Baseline task trial types.

\begin{tabular}{|c|c|c|c|c|c|c|c|}
\hline & \multicolumn{6}{|c|}{ Trial } \\
\hline & & 1 & 2 & 3 & 4 & 5 & 6 \\
\hline \multirow{6}{*}{ Trial } & 1 & & & $\mathrm{HS}$ & $\mathrm{HS}$ & & $\mathrm{HS}$ \\
\hline & 2 & & & & & & \\
\hline & 3 & & & & & & \\
\hline & 4 & & & & & $S$ & \\
\hline & 5 & & & & & & $S$ \\
\hline & 6 & & & & & & \\
\hline
\end{tabular}

Table 14 - Response times for each trial type in the Baseline task.

\begin{tabular}{|c|c|c|}
\hline \multirow{3}{*}{ Task } & Trial & $\begin{array}{c}\text { Average } \\
\text { RT }\end{array}$ \\
\hline \multirow{4}{*}{ Baseline } & 1 & 0.4903 \\
\cline { 2 - 3 } & 2 & 0.8037 \\
\cline { 2 - 3 } & 3 & 0.9443 \\
\cline { 2 - 3 } & 4 & 0.9905 \\
\cline { 2 - 3 } & 5 & 0.6634 \\
\cline { 2 - 3 } & 6 & 0.9708 \\
\hline
\end{tabular}

Upon completion of analysis of the stimulus-response results for the mental arithmetic task, it was found that trial type 1 was highly significantly different than type 4 
(p-value < 0.01) and significantly different than type 6 (p-value of 0.03 ). Tables 15 and 16 display the results graphically as well as the response times related to each trial.

Table 15 - Chart of significance for Mental Arithmetic task trial types.

\begin{tabular}{|c|c|c|c|c|c|c|c|}
\hline & \multicolumn{6}{|c|}{ Trial } \\
\hline & & 1 & 2 & 3 & 4 & 5 & 6 \\
\hline \multirow{6}{*}{ Trial } & 1 & & & & $\mathrm{HS}$ & & $S$ \\
\hline & 2 & & & & & & \\
\hline & 3 & & & & & & \\
\hline & 4 & & & & & & \\
\hline & 5 & & & & & & \\
\hline & 6 & & & & & & \\
\hline
\end{tabular}

Table 16 - Response times for each trial type in the Mental Arithmetic task.

\begin{tabular}{|c|c|c|}
\hline \multirow{3}{*}{ Task } & Trial & $\begin{array}{c}\text { Average } \\
\text { RT }\end{array}$ \\
\hline \multirow{4}{*}{$\begin{array}{c}\text { Mental } \\
\text { Arithmetic }\end{array}$} & 1 & 0.9976 \\
\cline { 2 - 3 } & 2 & 1.3093 \\
\cline { 2 - 3 } & 3 & 1.5607 \\
\cline { 2 - 3 } & 4 & 1.7782 \\
\cline { 2 - 3 } & 6 & 1.2644 \\
\hline
\end{tabular}

After analyzing the stimulus-response results for the directions task, it was found that trial type 1 was highly significantly different from types 3, 4, and 6 (p-values of $0.0018,0.000$, and 0.0001 respectively). It was also found that type 2 was highly significantly different from type 4 (p-value of 0.0075 ) as well as type 4 was highly significantly different than type 5 (p-value of 0.0021 ). Tables 17 and 18 display the results graphically as well as the response times related to each trial.

Table 17 - Chart of significance for Directions task trial types.

\begin{tabular}{|c|c|c|c|c|c|c|c|}
\hline & \multicolumn{6}{|c|}{ Trial } \\
\hline & & 1 & 2 & 3 & 4 & 5 & 6 \\
\hline \multirow{6}{*}{ Trial } & 1 & & & $\mathrm{HS}$ & $\mathrm{HS}$ & & $\mathrm{HS}$ \\
\hline & 2 & & & & $\mathrm{HS}$ & & \\
\hline & 3 & & & & & & \\
\hline & 4 & & & & & HS & \\
\hline & 5 & & & & & & \\
\hline & 6 & & & & & & \\
\hline
\end{tabular}


Table 18 - Response times for each trial type in the Directions task.

\begin{tabular}{|c|c|c|}
\hline \multirow{4}{*}{ Task } & Trial & $\begin{array}{c}\text { Average } \\
\text { RT }\end{array}$ \\
\hline \multirow{4}{*}{ Directions } & 1 & 0.8899 \\
\cline { 2 - 3 } & 2 & 1.1467 \\
\cline { 2 - 3 } & 3 & 1.2972 \\
\cline { 2 - 3 } & 4 & 1.4641 \\
\cline { 2 - 3 } & 5 & 1.0422 \\
\cline { 2 - 3 } & 6 & 1.3485 \\
\hline
\end{tabular}

Upon completion of analysis of the stimulus-response results for the synonyms task, it was found that trial type 1 was highly significantly different from type 3, 4, and 6 with p-values of $0.0088,0.0007$, and 0.0002 respectively. Trial type 5 was also significantly different than type 6 , with a p-value of 0.0273 . Tables 19 and 20 display the results graphically as well as the response times related to each trial.

Table 19 - Chart of significance for Synonyms task trial types.

\begin{tabular}{|c|c|c|c|c|c|c|c|}
\hline \multicolumn{2}{|c|}{} & \multicolumn{7}{|c|}{ Trial } \\
\cline { 2 - 8 } \multicolumn{1}{c|}{} & 1 & 2 & 3 & 4 & 5 & 6 \\
\hline \multirow{5}{*}{ Trial } & 1 & & & HS & HS & & HS \\
\cline { 2 - 8 } & 2 & & & & & & \\
\cline { 2 - 8 } & 3 & & & & & & \\
\cline { 2 - 8 } & 4 & & & & & & \\
\cline { 2 - 8 } & 5 & & & & & & S \\
\cline { 2 - 8 } & 6 & & & & & & \\
\hline
\end{tabular}

Table 20 - Response times for each trial type in the Synonyms task.

\begin{tabular}{|c|c|c|}
\hline \multirow{4}{*}{ Task } & Trial & $\begin{array}{c}\text { Average } \\
\text { RT }\end{array}$ \\
\hline \multirow{4}{*}{ Synonyms } & 1 & 0.6447 \\
\cline { 2 - 3 } & 2 & 0.8944 \\
\cline { 2 - 3 } & 3 & 1.0792 \\
\cline { 2 - 3 } & 4 & 1.1769 \\
\cline { 2 - 3 } & 5 & 0.8513 \\
\cline { 2 - 3 } & 6 & 1.1970 \\
\hline
\end{tabular}

After analysis of the stimulus-response results from the in person conversation task, it was found that trial type 1 was highly significantly different than types 2, 3, 4 and 6 (p-values of $0.0077,0.000,0.000$, and 0.0001 respectively). Trial type 2 was found to be highly significantly different than type 4 (p-value of 0.0015 ) as well as type 3 to be 
highly significantly different than type 5 (p-value of 0.0049 ). Trial type 4 was also found to be highly significantly different than type 5, with a p-value of 0.0000 . Tables 21 and 22 display the results graphically as well as the response times related to each trial.

Table 21 - Chart of significance for In Person Conversation task trial types.

\begin{tabular}{|c|c|c|c|c|c|c|c|}
\hline & \multicolumn{6}{|c|}{ Trial } \\
\hline & & 1 & 2 & 3 & 4 & 5 & 6 \\
\hline \multirow{6}{*}{ Trial } & 1 & & $\mathrm{HS}$ & $\mathrm{HS}$ & $\mathrm{HS}$ & & $\mathrm{HS}$ \\
\hline & 2 & & & & $\mathrm{HS}$ & & \\
\hline & 3 & & & & & HS & \\
\hline & 4 & & & & & $\mathrm{HS}$ & \\
\hline & 5 & & & & & & \\
\hline & 6 & & & & & & \\
\hline
\end{tabular}

Table 22 - Response times for each trial type in the In Person Conversation task.

\begin{tabular}{|c|c|c|}
\hline \multirow{3}{*}{ Task } & Trial & $\begin{array}{c}\text { Average } \\
\text { RT }\end{array}$ \\
\hline \multirow{4}{*}{$\begin{array}{c}\text { In } \\
\text { Person } \\
\text { Convo }\end{array}$} & 1 & 0.5608 \\
\cline { 2 - 3 } & 2 & 0.8021 \\
\cline { 2 - 3 } & 3 & 0.9869 \\
\cline { 2 - 3 } & 4 & 1.0901 \\
\cline { 2 - 3 } & 5 & 0.7136 \\
\hline
\end{tabular}

Upon completion of analysis of the stimulus-response results from the cell phone conversation task, it was found that trial type 1 was highly significantly different than types 3,4 , and 6 , with p-values of $0.0000,0.0000$, and 0.0001 respectively. Trial type 2 was highly significantly different than type 4 , with a p-value of 0.0091 . Trial type 3 was found to be significantly different than type 5 (p-value of 0.0118 ), and trial type 4 was found to be highly significantly different than type 5, with a p-value of 0.0011 . Trial type 5 was also found to be significantly different than type 6 , with a p-value of 0.0326 .

Tables 23 and 24 display the results graphically as well as the response times related to each trial. 
Table 23 - Chart of significance for Cell Phone Conversation task trial types.

\begin{tabular}{|c|c|c|c|c|c|c|c|}
\hline \multicolumn{2}{c|}{} & \multicolumn{7}{|c|}{ Trial } \\
\cline { 2 - 8 } \multicolumn{1}{c|}{} & 1 & 2 & 3 & 4 & 5 & 6 \\
\hline \multirow{4}{*}{ Trial } & 1 & & & HS & HS & & HS \\
\cline { 2 - 8 } & 2 & & & & HS & & \\
\cline { 2 - 8 } & 3 & & & & & S & \\
\cline { 2 - 8 } & 4 & & & & & HS & \\
\cline { 2 - 8 } & 5 & & & & & & S \\
\cline { 2 - 8 } & 6 & & & & & & \\
\hline
\end{tabular}

Table 24 - Response times for each trial type in the Cell Phone Conversation task.

\begin{tabular}{|c|c|c|}
\hline \multirow{4}{*}{ Task } & Trial & $\begin{array}{c}\text { Average } \\
\text { RT }\end{array}$ \\
\hline \multirow{4}{*}{$\begin{array}{c}\text { Cell } \\
\text { Convo }\end{array}$} & 1 & 0.5900 \\
\cline { 2 - 3 } & 2 & 0.8131 \\
\cline { 2 - 3 } & 3 & 1.0672 \\
\cline { 2 - 3 } & 4 & 1.1486 \\
\cline { 2 - 3 } & 5 & 0.7545 \\
\cline { 2 - 3 } & 6 & 1.0313 \\
\hline
\end{tabular}

Figures 4-9 display the confidence intervals associated with these results. 


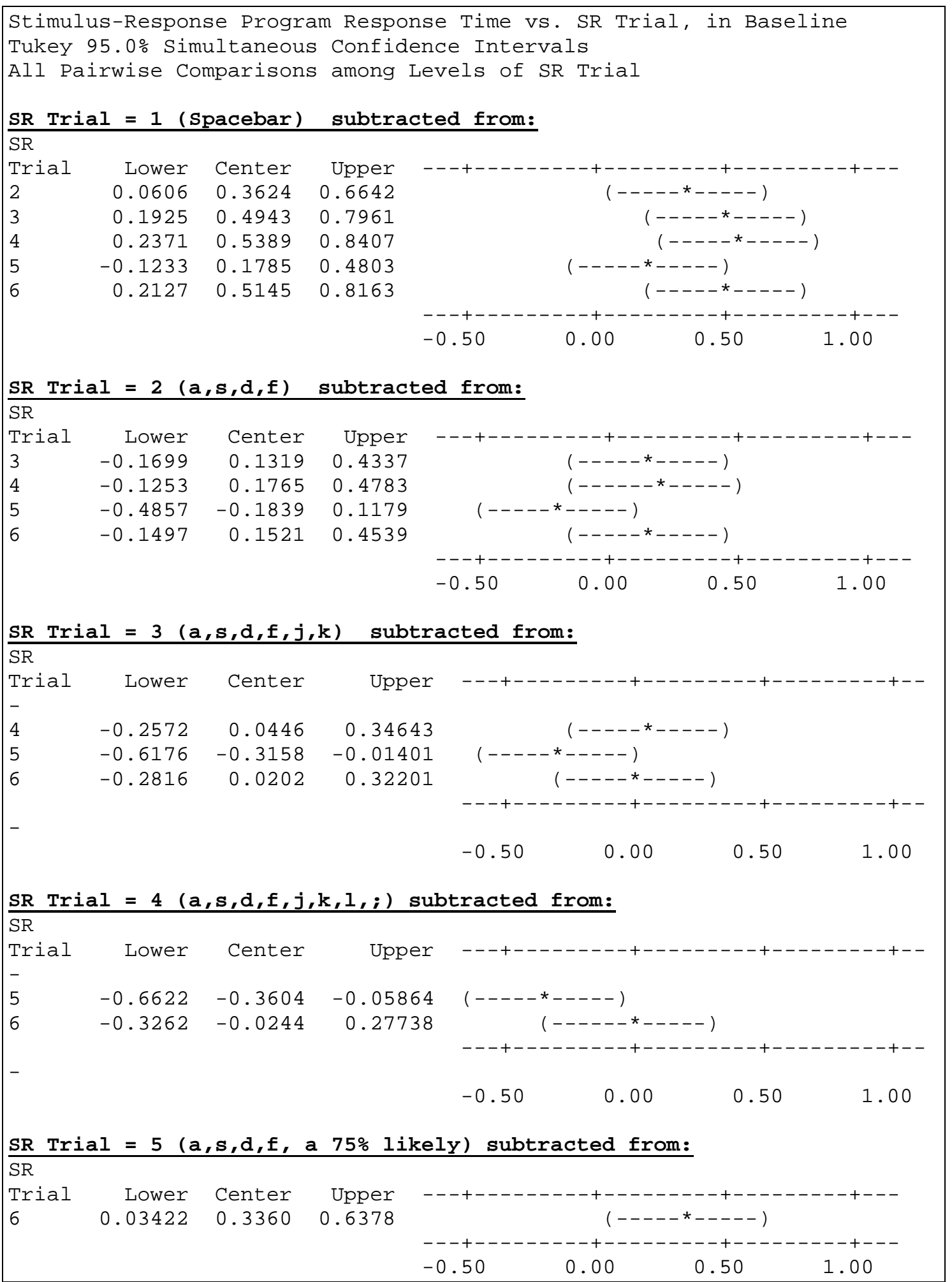

Figure 4 - Baseline Comparison Tests 


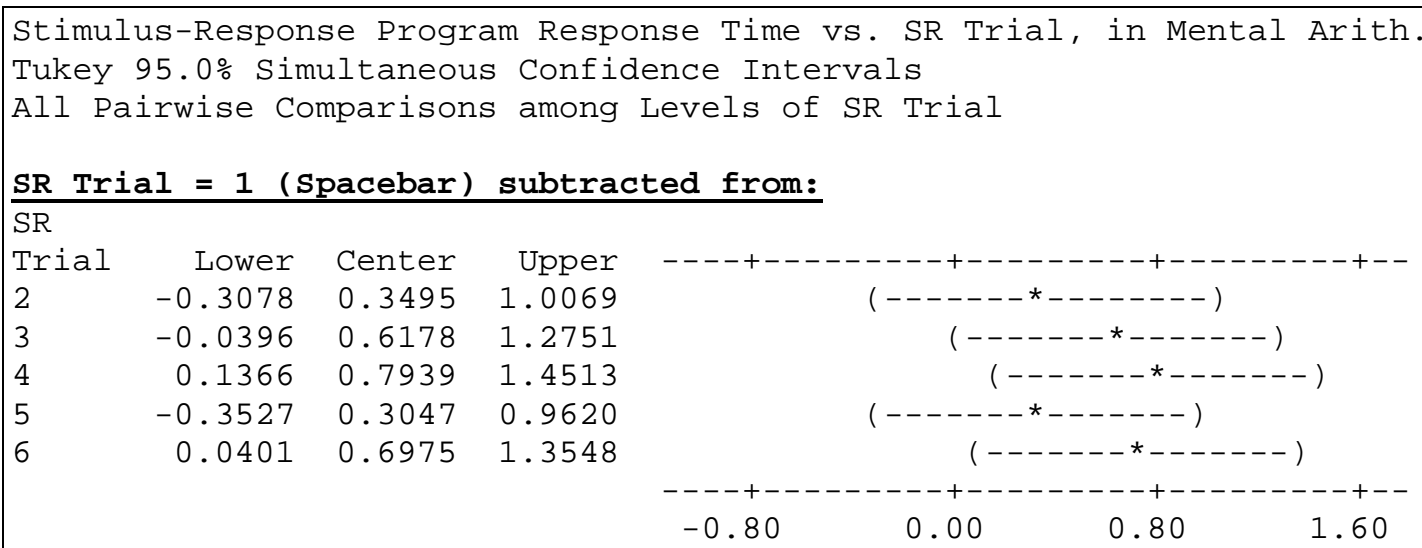

SR Trial $=2(a, s, d, f)$ subtracted from:

SR

$\begin{array}{lrrr}\text { Trial } & \text { Lower } & \text { Center } & \text { Upper } \\ 3 & -0.3891 & 0.26823 & 0.9256 \\ 4 & -0.2130 & 0.44438 & 1.1017 \\ 5 & -0.7022 & -0.04488 & 0.6125 \\ 6 & -0.3094 & 0.34794 & 1.0053\end{array}$

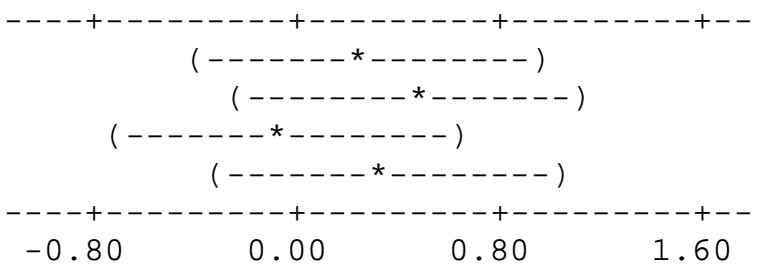

SR Trial $=3(a, s, d, f, j, k)$ subtracted from:

\begin{tabular}{lrrr}
\hline SR & & & \\
Trial & Lower & Center & Upper \\
4 & -0.4812 & 0.1761 & 0.8335 \\
5 & -0.9705 & -0.3131 & 0.3442 \\
6 & -0.5777 & 0.0797 & 0.7371
\end{tabular}

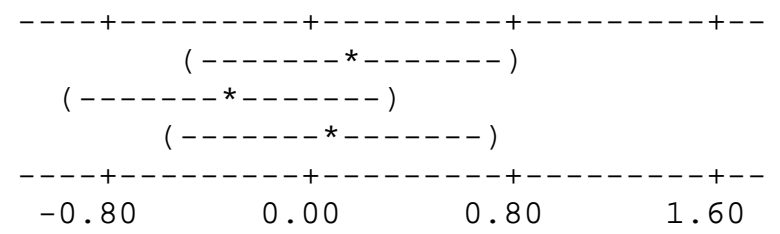

$\underline{\text { SR Trial }}=4(a, s, d, f, j, k, l, ;)$ subtracted from:

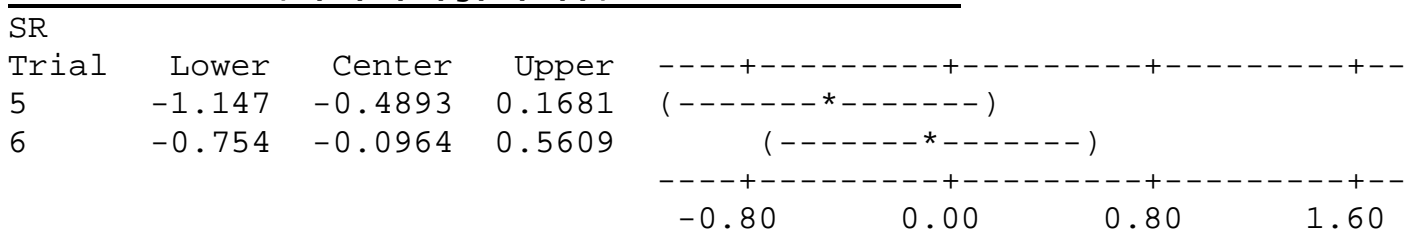

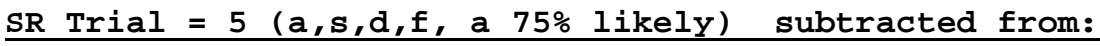

SR

Trial Lower Center Upper

$\begin{array}{llll}6 & -0.2645 & 0.3928 & 1.050\end{array}$

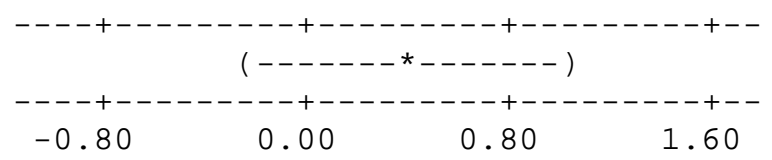

Figure 5 - Mental Arithmetic Comparison Tests 


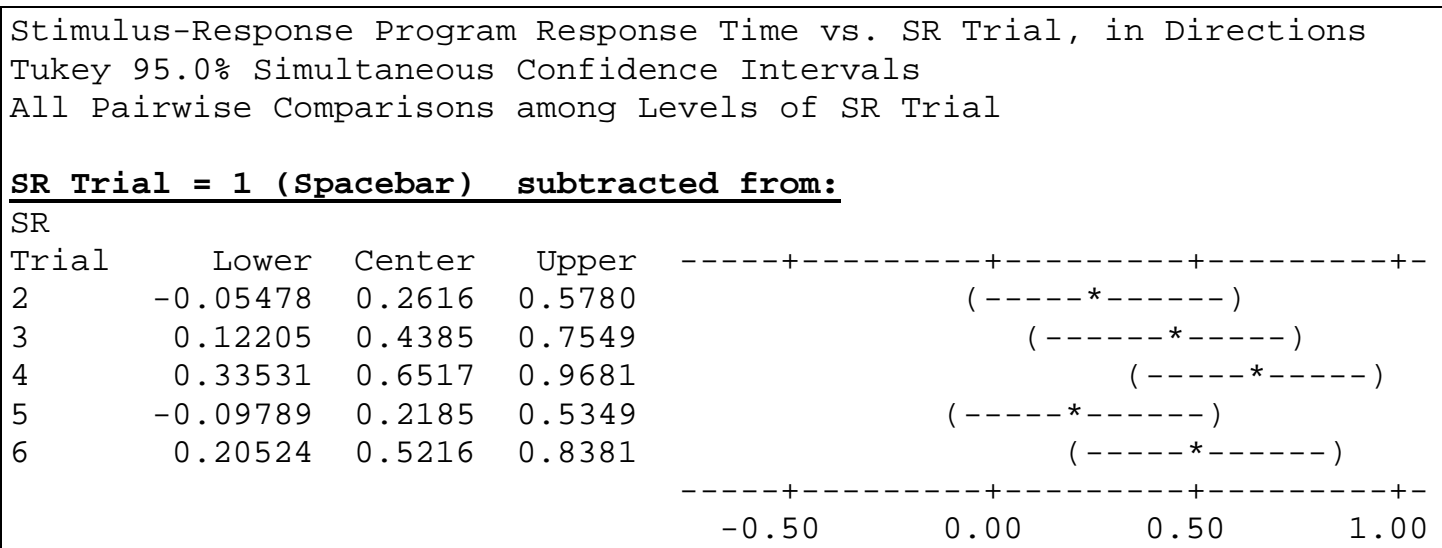

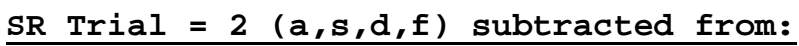

SR

$\begin{array}{lrrr}\text { Trial } & \text { Lower } & \text { Center } & \text { Upper } \\ 3 & -0.1396 & 0.17683 & 0.4932 \\ 4 & 0.0737 & 0.39009 & 0.7065 \\ 5 & -0.3595 & -0.04311 & 0.2733 \\ 6 & -0.0564 & 0.26002 & 0.5764\end{array}$

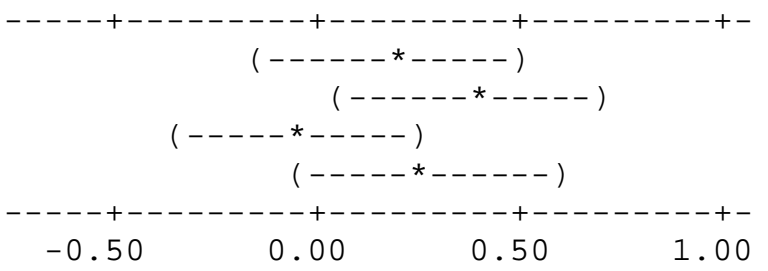

SR Trial $=3(a, s, d, f, j, k)$ subtracted from:

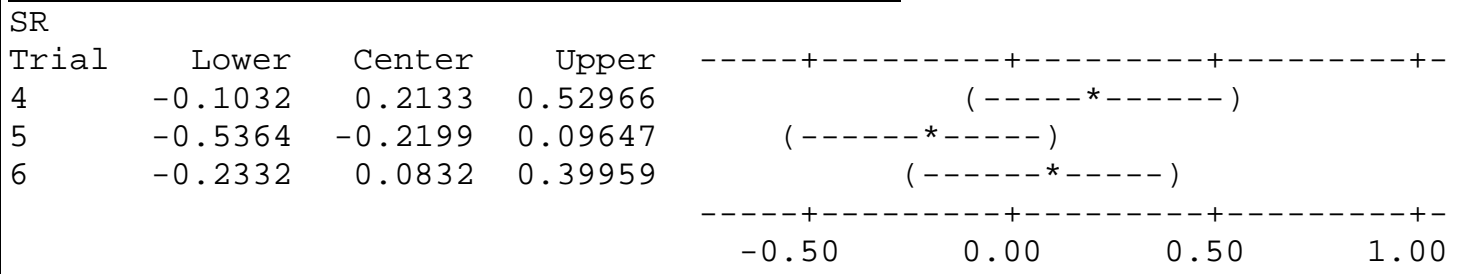

$\underline{\text { SR Trial }=4(a, s, d, f, j, k, l, ;) \text { subtracted from: }}$

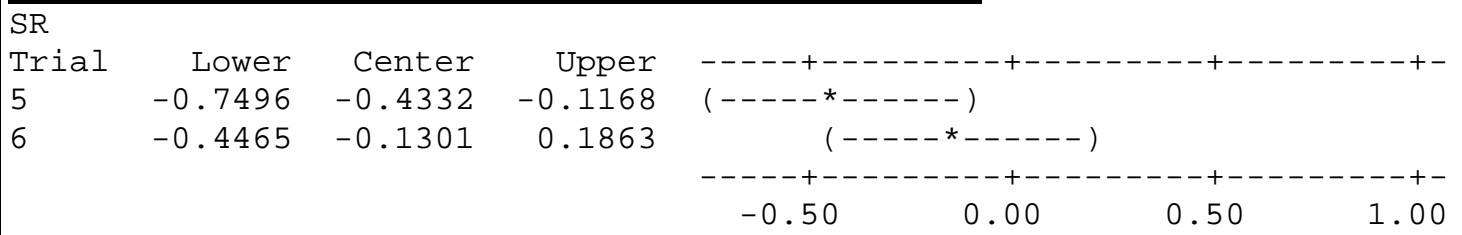

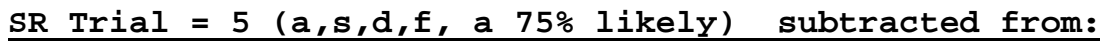

SR

Trial Lower Center Upper

$\begin{array}{lllll}6 & -0.01328 & 0.3031 & 0.6195\end{array}$

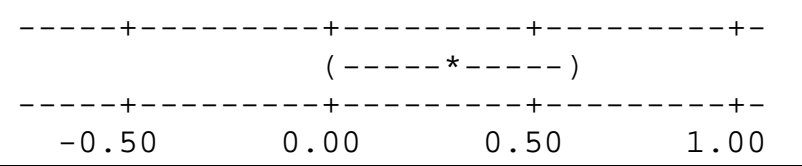

Figure 6 - Directions Comparison Tests 


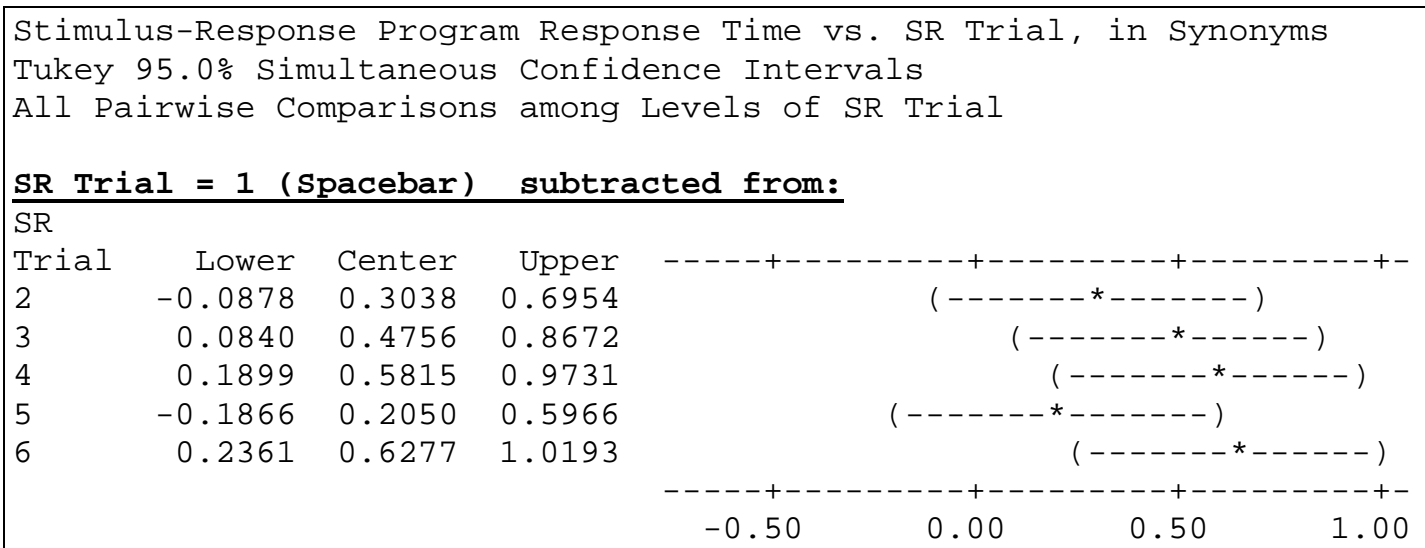

SR Trial $=2(a, s, d, f)$ subtracted from:

SR

Trial Lower Center Upper

$\begin{array}{llll}3 & -0.2198 & 0.17180 & 0.5634\end{array}$

$4 \quad-0.1139 \quad 0.27773 \quad 0.6693$

$\begin{array}{llll}5 & -0.4904 & -0.09879 & 0.2928\end{array}$

$\begin{array}{llll}6 & -0.0677 & 0.32389 & 0.7155\end{array}$

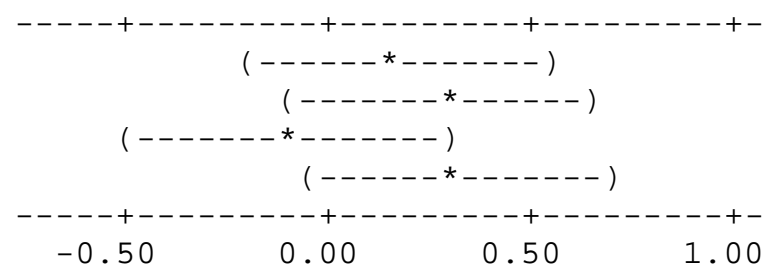

$\underline{\text { SR Trial }}=3(a, s, d, f, j, k)$ subtracted from:

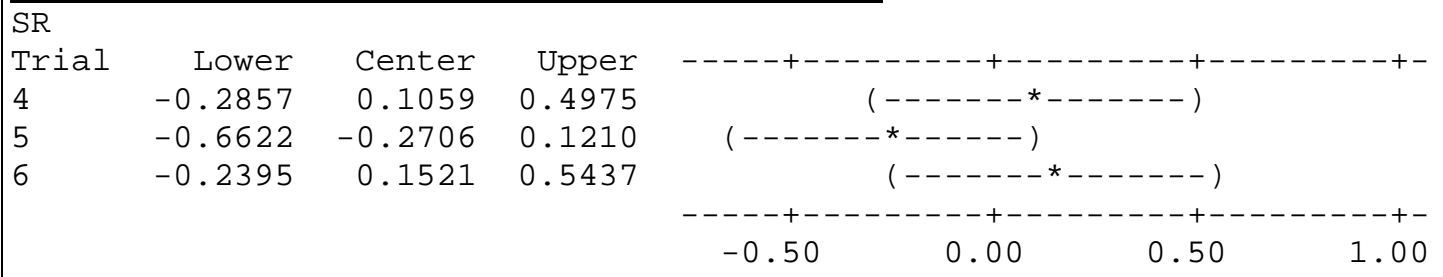

$\underline{\text { SR Trial }=4(a, s, d, f, j, k, l, ;) \text { subtracted from: }}$

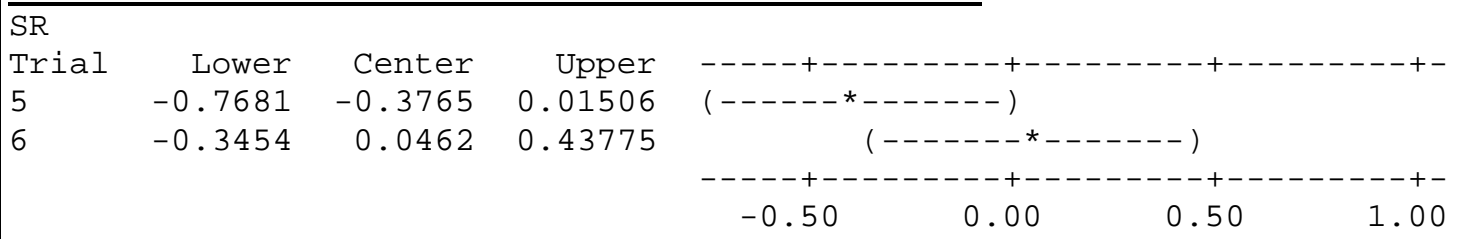

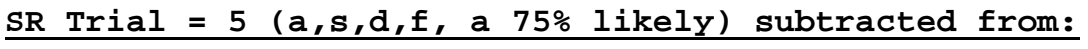

SR

Trial Lower Center Upper

$\begin{array}{llll}6 & 0.03110 & 0.4227 & 0.8143\end{array}$

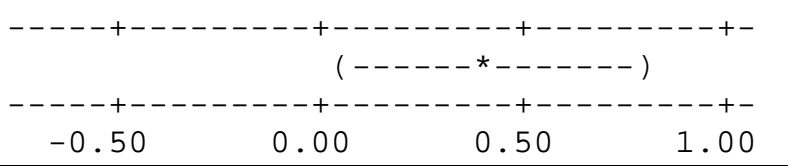

Figure 7 - Synonyms Comparison Tests 


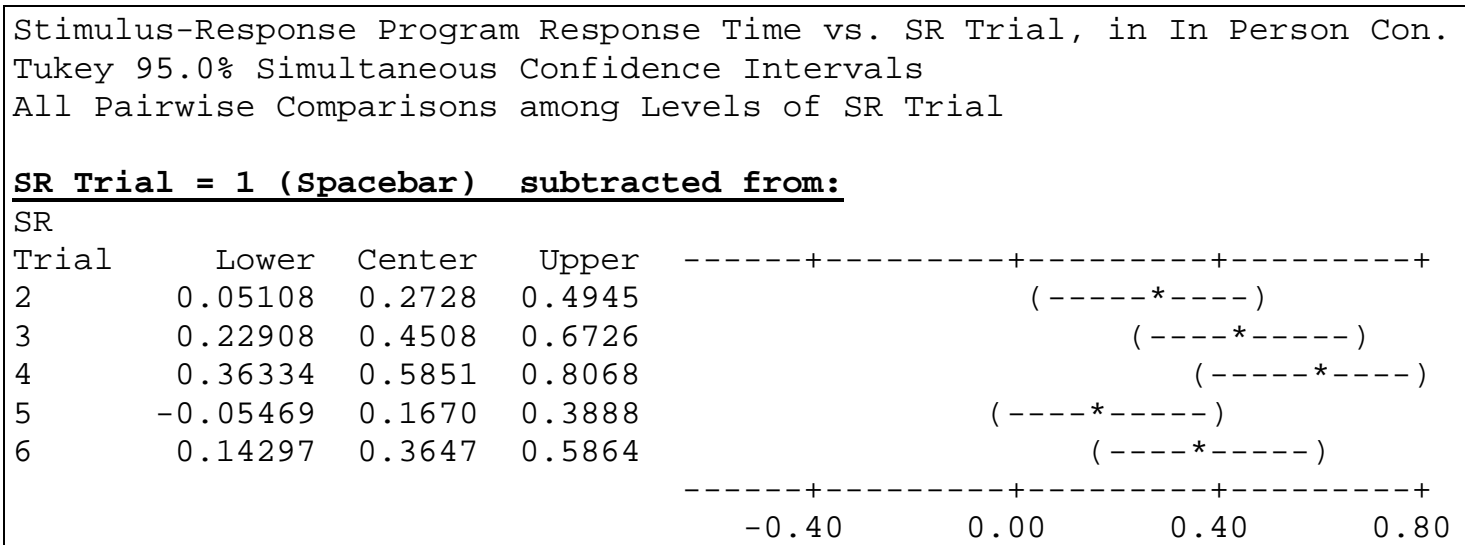

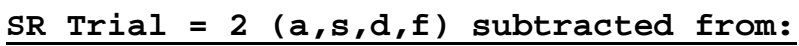

SR

$\begin{array}{lrrr}\text { Trial } & \text { Lower } & \text { Center } & \text { Upper } \\ 3 & -0.0437 & 0.1780 & 0.3997 \\ 4 & 0.0905 & 0.3123 & 0.5340 \\ 5 & -0.3275 & -0.1058 & 0.1160 \\ 6 & -0.1298 & 0.0919 & 0.3136\end{array}$

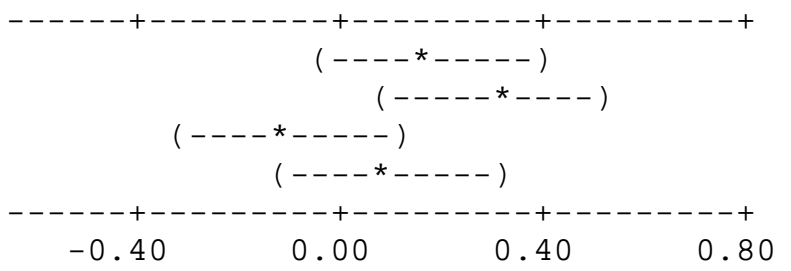

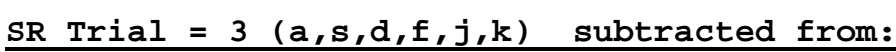

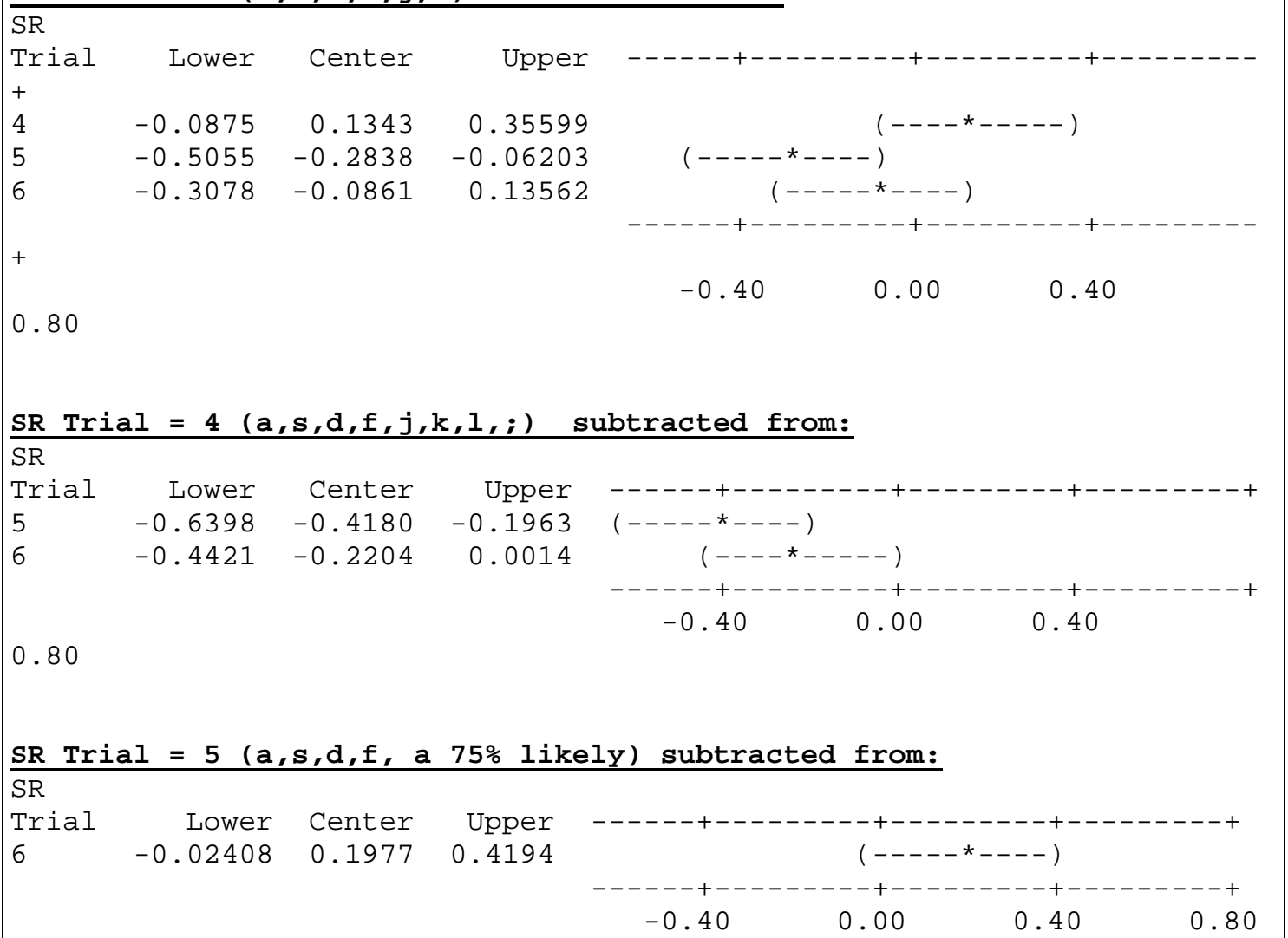

Figure 8 - In Person Conversation Comparison Tests 
Stimulus-Response Program Response Time vs. SR Trial, in Cell Phone Con Tukey 95.0\% Simultaneous Confidence Intervals

All Pairwise Comparisons among Levels of SR Trial

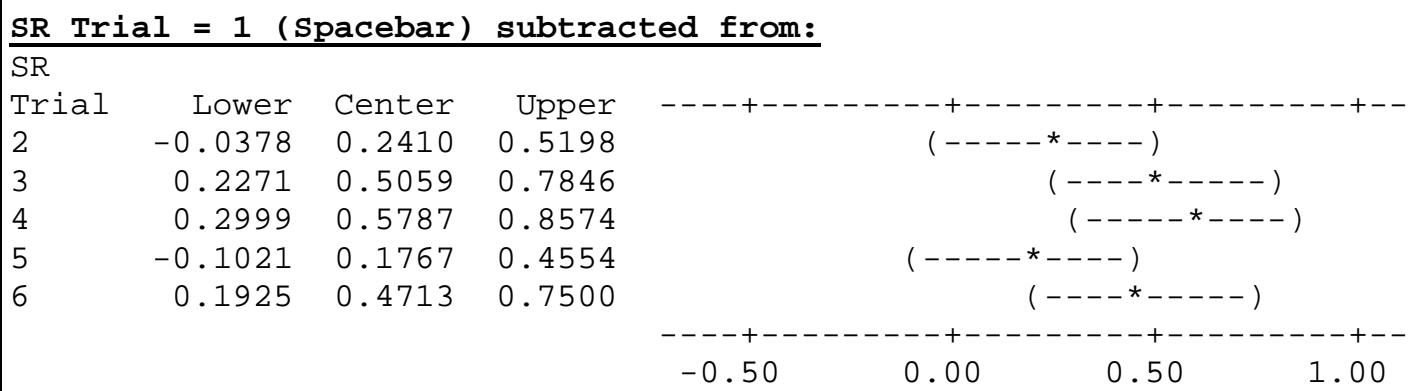

SR Trial $=2(a, s, d, f)$ subtracted from:

SR

Trial Lower Center Upper

$\begin{array}{llll}3 & -0.0139 & 0.26488 & 0.5436\end{array}$

$4 \quad 0.0589 \quad 0.33766 \quad 0.6164$

$\begin{array}{llll}5 & -0.3431 & -0.06431 & 0.2144\end{array}$

$\begin{array}{llll}6 & -0.0485 & 0.23026 & 0.5090\end{array}$

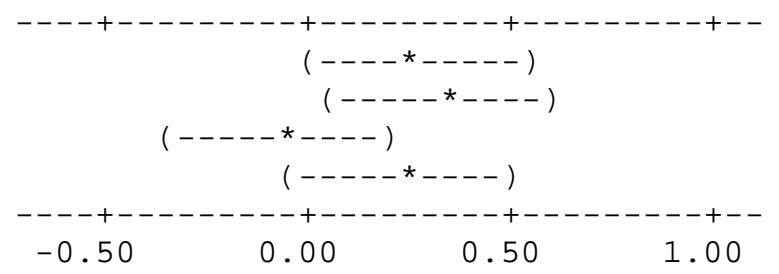

$\underline{S R}$ Trial $=3(a, s, d, f, j, k)$ subtracted from:

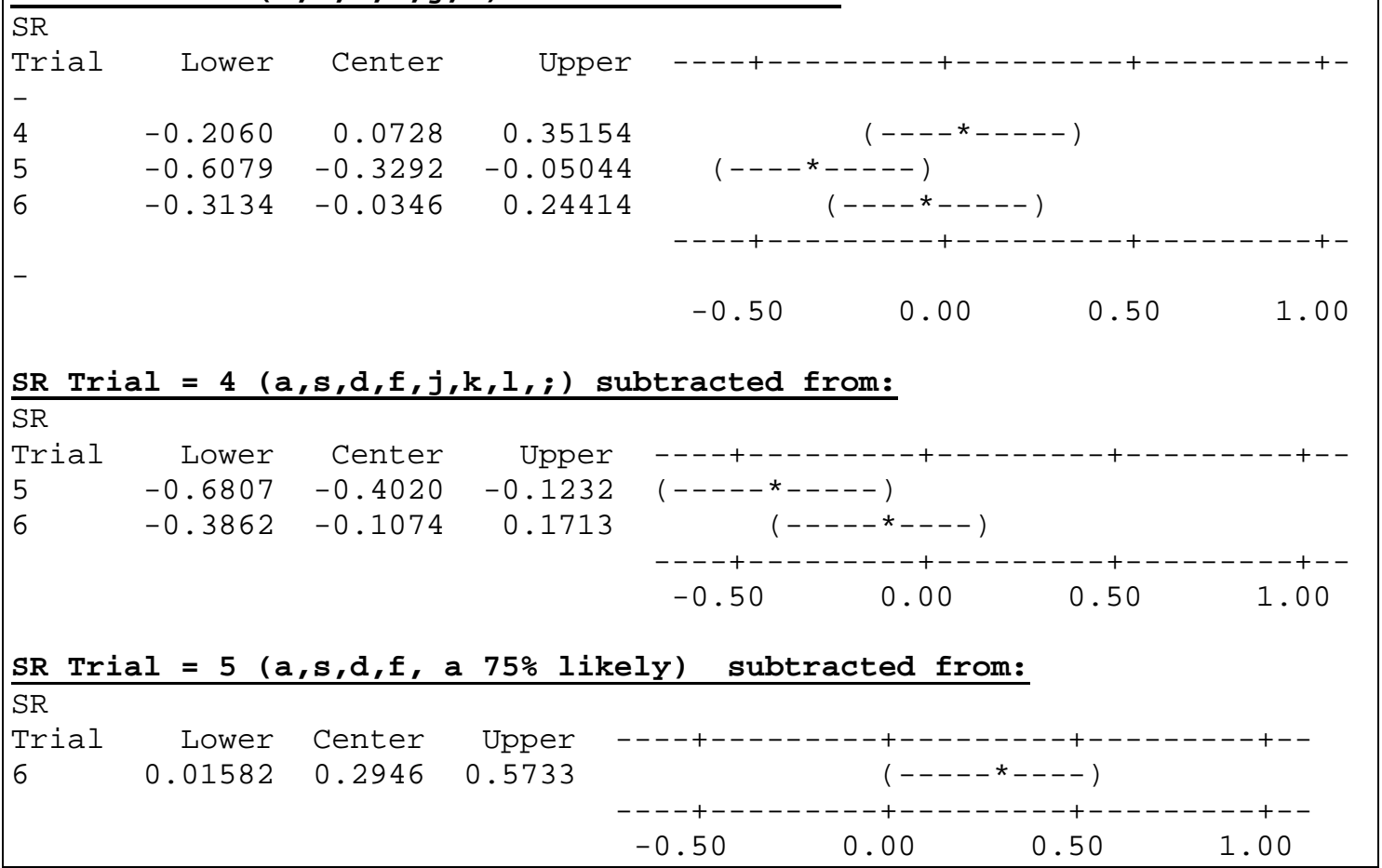

Figure 9 - Cell Phone Conversation Comparison Tests 


\subsection{Driving Video Analysis of Variance}

It was found that Task was the only factor to be found to be significantly different in the driving video program. A multiple comparison test was performed in Minitab, to determine which tasks had significant effects. The results follow in Figure 10. While no tasks were found to be significantly different from one another, there were significant trends. The baseline task showed a significant trend to be different from the directions task (p-value of 0.0818) and the directions task showed a significant trend to be different from the in-person conversation task ( $\mathrm{p}$-value of 0.0970). 


\begin{tabular}{|c|c|c|c|c|}
\hline \multicolumn{5}{|c|}{ Tukey Simultaneous Tests } \\
\hline Task & $=1$ (Baselin & subtrac & ed from: & \\
\hline & Difference & SE of & & Adjusted \\
\hline Task & of Means & Difference & T-Value & P-Value \\
\hline 2 & 0.192225 & 0.09860 & 1.94946 & 0.3844 \\
\hline 3 & 0.271187 & 0.09860 & 2.75026 & 0.0818 \\
\hline 4 & 0.063021 & 0.09860 & 0.63913 & 0.9875 \\
\hline 5 & 0.007317 & 0.09860 & 0.07420 & 1.0000 \\
\hline 6 & 0.116858 & 0.09860 & 1.18512 & 0.8420 \\
\hline
\end{tabular}

Task = 2 (Mental Arithmetic) subtracted from:

$\begin{array}{lrrrr} & \text { Difference } & \text { SE of } & & \text { Adjusted } \\ \text { Task } & \text { of Means } & \text { Difference } & \text { T-Value } & \text { P-Value } \\ 3 & 0.0790 & 0.09860 & 0.801 & 0.9662 \\ 4 & -0.1292 & 0.09860 & -1.310 & 0.7781 \\ 5 & -0.1849 & 0.09860 & -1.875 & 0.4282 \\ 6 & -0.0754 & 0.09860 & -0.764 & 0.9723\end{array}$

$\begin{array}{lrrrr}\text { Task } & \mathbf{3} \text { (Directions) } & \text { subtracted from: } & \\ & \text { Difference } & \text { SE of } & & \text { Adjusted } \\ \text { Task } & \text { of Means } & \text { Difference } & \text { T-Value } & \text { P-Value } \\ 4 & -0.2082 & 0.09860 & -2.111 & 0.2972 \\ 5 & -0.2639 & 0.09860 & -2.676 & 0.0970 * \\ 6 & -0.1543 & 0.09860 & -1.565 & 0.6245\end{array}$

Task = 4 (Synonyms) subtracted from:

Difference SE of Adjusted

$\begin{array}{lrrrr}\text { Task } & \text { of Means } & \text { Difference } & \text { T-Value } & \text { P-Value } \\ 5 & -0.05570 & 0.09860 & -0.5649 & 0.9929 \\ 6 & 0.05384 & 0.09860 & 0.5460 & 0.9939\end{array}$

Task = 5 (In-Person Conversation) subtracted from:

Difference SE of Adjusted

Task of Means Difference T-Value P-Value

$\begin{array}{lllll}6 & 0.1095 & 0.09860 & 1.111 & 0.8748\end{array}$

Figure 10 - Multiple Comparison Test for Tasks 


\subsection{Driving Video Percent Misses}

At completion of this study, the average number (across all subjects) of misses per task and the maximum consecutive (across all subjects) misses per task were analyzed. Figure 11 displays this information graphically.

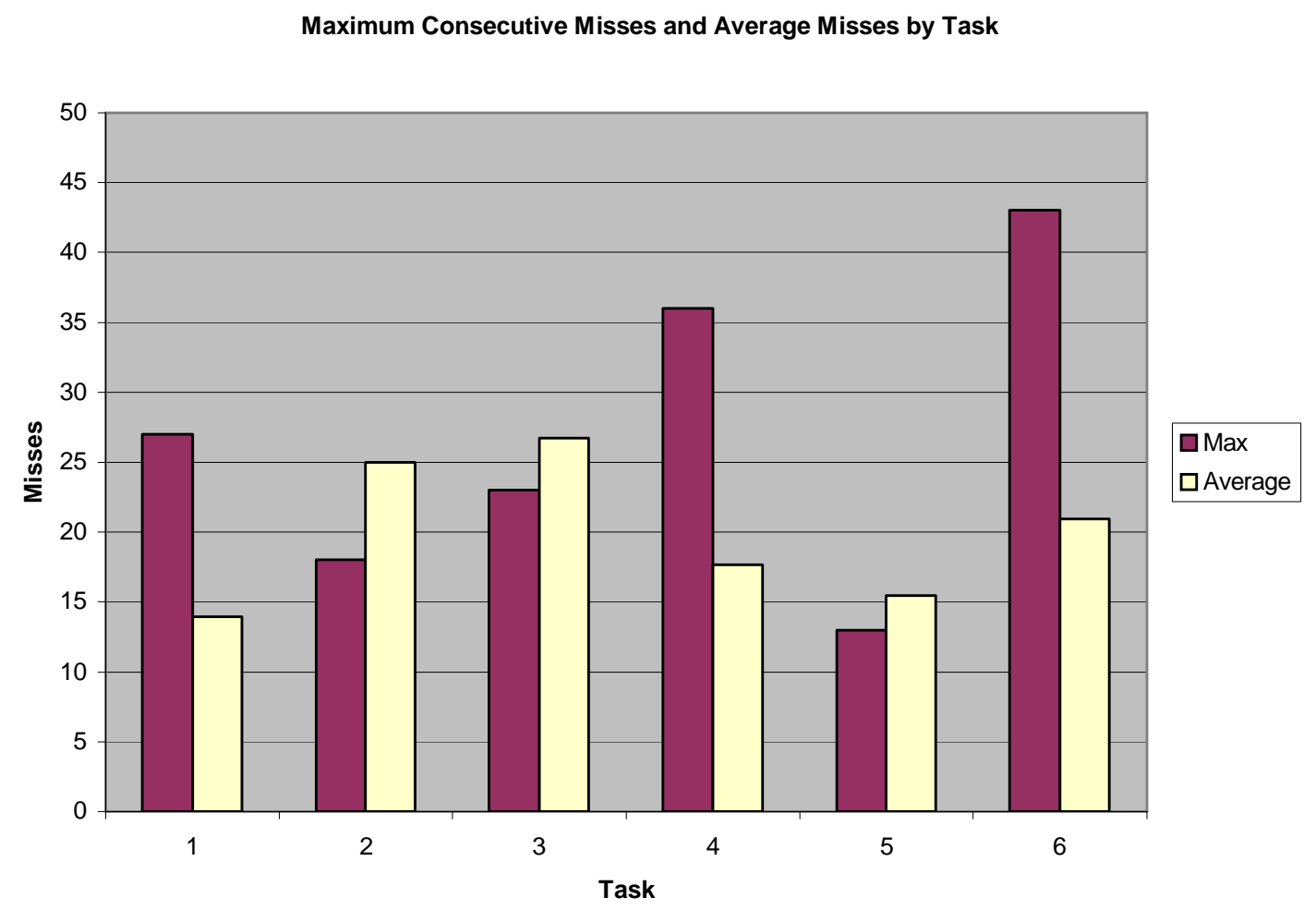

Figure 11 - Maximum Consecutive Misses per Task and Average Misses per Task

After inspection of the data it was determined that one subject had much more difficulty completing this portion of the experiment than any of the other subjects. This subject's average number of misses and maximum consecutive misses had values at least 10 more than any other subject's. In order to realistically interpret the data, the subject's data was discarded. After discarding this subject's data, the following graph was produced (Figure 12). For the duration of this paper, the results in Figure 12 will be used. 


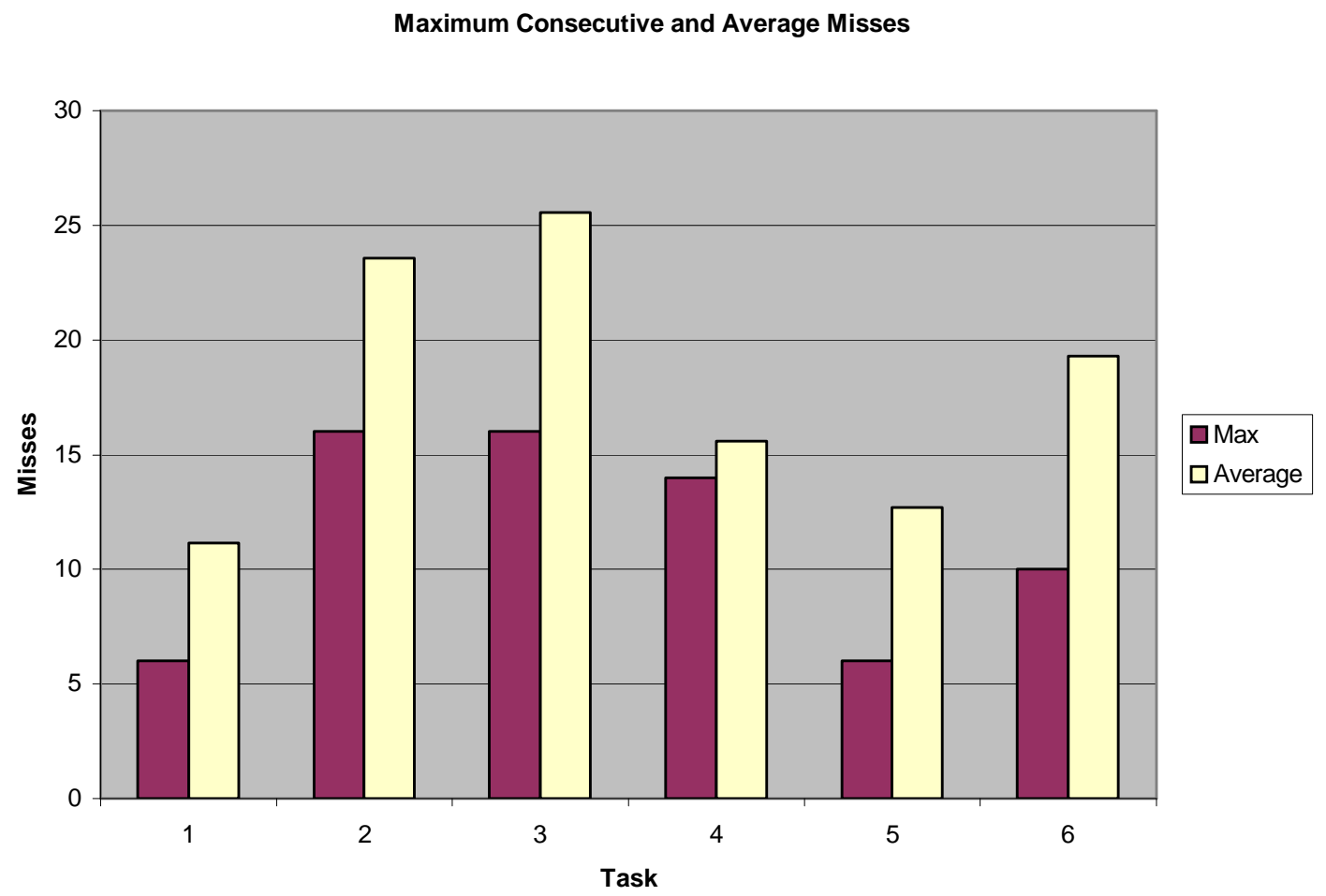

Figure 12 - Maximum Consecutive Misses per Task and Average Misses per Task, after elimination of outliers. 


\section{DISCUSSION}

The main objective of this study was to determine the effects of cognitive tasks on the ability of a driver to identify hazards that may occur on the roadway. Previous research has found that conversing on a cell phone can increase braking response time by up to $24 \%$ (Irwin et al., 2000). Other studies have also compared the distraction of cell phone conversation to changing radio stations, conversing with a passenger, and driving under the influence of alcohol, among others (Strayer, Drews, and Crouch, 2006; Redelmeier \& Tibshirani, 1997; Esbjornsson and Juhlin, 2003; Hunton and Rose, 2005; Consiglio et al, 2003). However, these studies have not identified the underlying cause for such degradation in primary task performance. Due to previous research (Strayer, Drews, and Johnston, 2003 and McCarley, et al., 2001) in which it was suggested that drivers were less attentive to visual scenarios when conversing on a cell phone, it was hypothesized in this experiment that tasks requiring mental imagery would cause greater task degradation than tasks not requiring mental imagery. This suggests "inattention blindness", which can be defined as "withdrawing attention from the visual scene" (Strayer, Drews, and Johnston, 2003). We found that tasks such as giving directions and performing mental arithmetic were highly significantly different from the baseline in the stimulus-response program implying that tasks involving mental imagery are more distracting, and may indeed cause inattention blindness. Strayer, Drews, and Johnston (2003) have conducted research that suggests "even when the participants eyes were directed at objects in the driving environment, they were less likely to remember them if they were conversing on a cell phone" (Strayer, et al, 2003).

Brookhuis, De Vries, and De Waard (1991) found that as demands of a task increase, heart rate and heart rate variability also increase. This is supported by previous research that suggest that "participants were finding task performance cognitively more effortful in the 'during call period', and were having to invest greater attentional resources in task performance" (Haigney, et al, 2000).

Overall, it was found that age and gender were significant factors in this study. After a multiple comparison test it was discovered that the age group of 21-30 years was significantly different than the age group 41-50 (p-value of 0.0298). When examining Table 7, it becomes apparent that the age category of 41-50 responded slower than either 
of the other two age categories in all tasks, except mental arithmetic. This could be due to younger generartions' dependence on technology to perform simple arithmetic. Also, gender was found to be significant. Upon further inspection of the average response times for each task, it was determined than men responded more quickly than women. This could be for varying reasons, but it is important to note that the correctness of responses was not considered in this experiment.

It was expected that cell phone conversation and in-person conversation would be significantly different, due to the results of previous research (Esbjornsson and Juhlin, 2003; Hunton and Rose, 2005; Consiglio et al, 2003; Gugerty, Rakauskas, and Brooks, 2004). Although this study did not find that to be true, both types of conversations were found to be significantly different from a baseline task. It is also interesting to point out that the other task that involves verbal communication (synonyms) was not significantly different from either type of conversation task, possibly due to the area of the brain being utilized. All three of these tasks (cell phone conversation, in person conversation, and synonyms) were highly significantly different from the directions task and mental arithmetic task. The directions task and the mental arithmetic task generally require the subject to mentally visualize the routes to be taken or the numbers to add or subtract. The fact that these tasks were significantly different from communication tasks further suggests that tasks requiring mental imagery are more distracting to drivers than verbal tasks.

It is also possible that the conversations held during the experiment were unnatural or forced conversations. It is very difficult to categorize the different types of conversations held while on a cell phone, or in person. While the subjects were using the verbal regions of the brain, the conversation may not have differed in substantive content as they may or may not do in a realistic setting.

To further support this theory, it is important to note that there was a significant difference in response time for one subject when comparing cell phone and in person conversation for trial type 2 and type 4 . Based on subjective observation, this subject had a very serious conversation on the cell phone discussing the personal safety of someone in his family. This was much more distracting than the in-person conversation in which a discussion of kitchen supplies was held. 
It is possible that the results in this study do not reflect a difference between cell phone and in-person conversation due to the fact that cell phone and in person conversations differ on the nature of what is discussed. Upon observation, cell phone conversations typically involve discussing business matters or making plans for the future. In-person conversations are sometimes much more personal and involve the "here $\&$ now". It is also possible that the results do not reflect a difference between cell phone and in-person conversation due to the length of each stimulus-response trial. Each trial was approximately 8 minutes in length, and during the 8 -minute period, several different topics of discussion could be introduced. It is possible that some subjects discussed "light" topics, such as the weather, current events, or work, while other subjects discussed more in-depth topics such as illness, politics, or safety of family. Upon further consideration, the differences in the two types of conversations should be researched thoroughly and controlled during an experiment. This may result in a more clear understanding of the problem caused by cell phones. It is possible that cell phone conversations are typically "futuristic", requiring the brain to focus on what is not presented during the actual conversation.

When comparing trial types, it was found that trial 2 (selecting a, s, d, or f) was highly significantly different from trials 3 (selecting a, s, d, f, j, or k), 4 (selecting a, s, d, $\mathrm{f}, \mathrm{j}, \mathrm{k}, \mathrm{l}$, or ;), and 6 (selecting a, d, j, or k). Trial 2 was not found to be significantly different from trial 5, which is expected due to the similarity between the trials. In trial 2 subjects must choose between a, s, d, or f, and in trial 5 subjects must choose between a, $\mathrm{s}, \mathrm{d}$, or f, with "a" $75 \%$ more likely. It was also expected that trial 3 would not be significantly different from 4 and 6, due to the difficulty of all three tasks. In trial 3 subjects must select among 6 choices, in trial 4 subjects must select among 8 choices, and in trial 6 subjects must select among 4 incompatible choices.

Results were not as obvious in the driving portion of the experiment; however the analysis of variance revealed the only significant factor to be Task (p-value of 0.05). A significant trend in the data also suggests that the Directions task is different from the Baseline task (0.0818) and the Directions task is different from the In Person Conversation task (0.0970). The lack of significance in the data can probably be ascribed to the lack of enough data. The significant trends found in the driving video portion of 
this experiment tend to agree with results from the stimulus-response program results, and upon further testing of more subjects, it is predicted that the results would suggest Task to be highly significant as well.

It was expected that the number of misses and the maximum consecutive misses in the driving video portion of the experiment would be greater for tasks requiring mental imagery. This was supported by the results of the experiment. The maximum number of consecutive misses and average number of misses for each task were calculated, and it was found that the directions task had the highest maximum consecutive misses as well as the highest average of misses. The mental arithmetic task came in second. The baseline task, in-person conversation task, and cell phone conversation task appear to be the least distracting among the six tasks. These results further imply that tasks requiring mental imagery may cause inattention blindness, in which the subject is looking at the stimuli presented in front of them, but is not responding to it. The high number of consecutive misses suggests that subjects were not effectively switching attention between tasks throughout the experiment. It is likely that when a subject was visualizing directions to a location or how to perform a math problem, his or her visual attention was not focused on the driving scene presented.

This experiment was conducted in a simulated driving environment, and a more precise driving simulator may produce more clear results. While the paradigm used in this study was acceptable, future studies involving scanning of the brain's activity while participating in the study would be useful to identify the causes of the inattention blindness. The results presented here suggest that visual mental imagery prohibits fullattention to the primary task (driving) and further investigation into the activity of the visual cortex during verbal task suggesting imagery, such as giving directions, would be beneficial to the research community.

While the results do not suggest laboratory findings translate directly to the "real world" of our roadways, it is important to consider the implications of the results found. Factors that may distract drivers from the primary task of driving, such as giving directions and performing mental math present a significant hazard to drivers as well as passengers. While these two tasks may not seem to be common tasks drivers perform, they occur daily. Drivers may be listening to directions from a GPS navigator, and then 
begin to re-route themselves based on a "short-cut route" they remember. The process of thinking through a route is suggested here to be one of the most distracting behaviors for drivers. It is also possible that conducting a business call while driving may also prove to be a hazardous distraction. The conversation itself may not be highly distracting, but giving an "off the top" estimate for a bid is suggested to be extremely distracting.

This research helps to promote the dangers of distraction while driving. Again, conversing on a cell phone is only one among many distracting tasks such as changing radio stations, conversing with a passenger, attending to children, and adjusting other incabin controls. However, using a cell phone may be an additional distraction to factors this study already found to be distracting. Perhaps a driver is performing mental arithmetic while conversing on a cell phone, or relaying directions during a cell phone conversation. The combination of these distractions pose a threat to the roadways, and further research should be conducted to narrow the causes of this distraction.

Limitations of this study include a small pool of subjects $(n=16)$. While the data obtained from the stimulus-response program provided enough data points to complete an analysis of variance that resulted in many highly significant factors, there was not enough data to find many significant factors in the driving video response program due to increased variability. In order to obtain a more realistic amount of data, this experiment would benefit from many more subjects, and a more detailed driving simulator. A second experiment based on the brain activity during the same tasks would also be a unique successor of the current experiment.

While the age range in this experiment was rather broad (ages 23-50), a wider subject age range would possibly show even stronger effects between age groups. Young drivers (those newly licensed, between the ages of 16 and 20) and older drivers (50+) may produce similar results to each other, due to lack of experience with the roadway, or with technology.

While there were limitations to this study, the results found in the stimulusresponse program suggest strong significance. The driving-video portion did show strong significant trends, and upon further studies it is expected that the results will mimic those found in the stimulus-response program due to the significant trends in the data. The data 
displays the expected results, suggesting that visual mental imagery does occur during certain tasks, and this imagery may create a form of "inattention blindness".

In conclusion, driving while using a cell phone poses a distraction, along with many other tasks that are commonly performed in the car. This research helps to promote educating the public on the dangers of driving while conversing on a cell phone, and why these dangers exist. It is possible that if drivers were aware of the types of activities that cause inattention blindness they may be more aware of their actions while driving. It is recommended that government officials should engage in more active campaigning to teach the public about the dangers of driving while distracted by conversations, not just the act of holding a cell phone. It is also suggested that further research be conducted in order to determine if there are major characteristics that differ between cell phone conversations and in-person conversations. The most important recommendation suggests that if at all possible, visual distractions should be avoided at all costs while performing the primary task of maneuvering an automobile. 


\section{REFERENCES}

Alm, Hakan and Nilsson, Lena. "The effects of a mobile phone task on driver behaviour in a car following situation." Accident Analysis \& Prevention. 27.5 (1995): 707715.

Amado, Sonia and Ulupmar, Pinar. "The effects of conversation on attention and peripheral detection: Is talking with a passenger and talking on the cell phone different?" Transportation Research, Part F. 8.6 (2005): 383- 395.

"Background on CTIA's Semi-Annual Wireless Industry Survey." Cellular Telecommunications Industry Association - The Wireless Association. 2006.

Baker, Robert W. and Madell, Thomas O. "A Continued Investigation of Susceptibility to Distraction in Academically Underachieving and Achieving Male College Students." Journal of Educational Psychology. 56.5 (1965): 254-258.

Beede, Kristen E. and Kass, Steven J. "Engrossed in conversation: The impact of cell phones on simulated driving performance." Accident Analysis and Prevention. 38.2 (2005): 415-421.

Belojevic, G., Jakovljevic, B, and Slepcevic, V. "Noise and mental performance: Personality attributes and noise sensitivity." Noise \& Health. 6.21 (2003): 77-89.

Boles, David B. and Law, Mark B. "A Simultaneous Task Comparision of Differentiated and Undifferentiated Hemispheric Resource Theories." Journal of Experimental Psychology: Human Perception and Performance. 24.1 (1998): 204-215.

Brookhuis, Karel A., De Vries, Gerbrand, and De Waard, Dick. "The Effects of Mobile Telephoning on Driving Performance." Accident Analysis and Prevention. 23.4 (1991): 309-316.

Consiglio, William, Driscoll, Peter, Witte, Matthew, and Berg, William. "Effect of cellular telephone conversations and other potential interference on reaction time in a braking response." Accident Analysis and Prevention. 35 (2003): 495- 500.

Esbjornsson, Mattias and Juhlin, Oskar. "Combining Mobile Phone Conversations and Driving - Studying a Mundane Activity in Its Naturalistic Setting." The Interactive Institute. (2003): 92.

Eysenck, Michael W. and Graydon, Jan. "Susceptibility to Distraction as a Function of Personality.” Personality and Individual Differences. 10.6 (1989): 681-687.

Glass, Daivd C., Krakoff, Lawrence R., Finkelman, Jay, et. al. "Effect of Task Overload Upon Cardiovascular and Plasma Catecholamine Responses in Type A and B Individuals." Basic and Applied Social Psychology. 1.3 (1980): 199-218. 
Governors Highway Safety Association. June 2007. GHSA. 4 September 2007. http://www.ghsa.org/html/stateinfo/laws/cellphone_laws.html

Gugerty, Leo, Rakauskas, Mick, and Brooks, Johnell. "Effects of remote and in-person verbal interactions on verbalization rates and attention to dynamic spatial scenes." Accident Analysis and Prevention. 36 (2004): 1029-1043.

Haigney, D.E., Taylor, R.G., and Westerman, S.J. "Concurrent mobile (cellular) phone use and driving performance: task demand characteristics and compensatory processes." Transportation Research, Part F. 3.3 (2000): 113-121.

Heath AM, Rider KA (2007) "The impact of cell phone classification and experience on driver distraction," MS thesis, West Virginia University.

Horrey, William J. and Wickens, Christopher D. "Examining the Impact of Cell Phone Conversations on Driving Using Meta-Analytic Techniques.” Human Factors. 48.1 (2006): 196-205.

Huguet, Pascal, Galvaing, Marie P., Monteil, Jean M., and Dumas, Florence. "Social Presence Effects in the Stroop Task: Further Evidence for an Attentional View of Social Facilitation." Journal of Personality and Social Psychology. 77.5 (1999): 1011-1025.

Hunton, James and Rose, Jacob M. "Cellular Telephones and Driving Performance: The Effects of Attentional Demands on Motor Vehicle Crash Risk." Risk Analysis. 25.4 (2005): 855-866.

Insurance Information Institute Media. August 2007. Insurance Information Institute, Inc. 4 September 2007. http://www.iii.org/media/hottopics/insurance/cellphones/

Irwin, M., Fitzgerald, C. and Berg, W. "Effect of the intensity of wireless telephone conversations on reaction time in a braking response." Perceptual and Motor Skills. 90 (2000): 1130-1134.

Katz, Mory. "Are the Nation's Drivers Driven to Distraction?" San Diego Business Journal. 22.30 (2001): 43.

Lamble, Dave, Kauranen, Tatu, Laakso, Matti, and Summala, Heikki. "Cognitive load and detection thresholds in car following situations: safety implications for using mobile (cellular) telephones while driving." Accident Analysis and Prevention. 31.6 (1999): 617-623.

Lewis, Michael. “Michael Lewis' Home Page.” University of Pittsburgh. 15 May 2008. <http://www.pitt.edu/ cmlewis/RT.zip>. 
Matthews, Roland, Legg, Stephen, and Charlton, Samuel. "The effect of cell phone type on drivers subjective workload during concurrent driving and conversing." Accident Analysis and Prevention. 35.4 (2003): 451-457.

McCarley, Jason S., Vais, Margaret., Pringle, Heather, Kramer, Arthur F., et al. "Conversation Disrupts Visual Scanning of Traffic Scenes." 18 February 2008. www.psych.utah.edu/AppliedCognitionLab/ViV_2001.pdf

McEvoy, Suzanne, Stevenson, Mark R., McCartt, Anne, Woodward, Mark, et al. "Role of mobile phones in motor vehicle crashes resulting in hospital attendance: a case crossover study." British Medical Journal. 12 July 2005.

Mulligan, Neil W. and Hartman, Marilyn. "Divided Attention and Indirect Memory Tests." Memory \& Cognition. 24.4 (1996): 453-465.

National Highway Traffic Safety Administration. "Crash Data Relating to Cellular Telephone Use While Driving.” 18 April 2008.

<http://www.nhtsa.dot.gov/people/injury/research/wireless/c3.htm\#nass>

"Nationwide survey shows startling number of Americans guilty of driving while distracted." Press Release. Nationwide Mutual Insurance, Co. 22 January 2007.

“Reaction time.” Encarta. Microsoft, 2007. 18 April 2008.

<http://encarta.msn.com/encnet/refpages/search.aspx?q=reaction+time>

Redelmeier, Donald A. and Tibshirani, Robert J. "Association Between CellularTelephone Calls and Motor Vehicle Collisions." The New England Journal of Medicine. 336.7 (1997) 453- 458.

“Response." Encarta. Microsoft, 2007. 18 April 2008.

<http://encarta.msn.com/encnet/refpages/search.aspx?q=response>

Rosenbloom, Tova. "Driving performance while using cell phones: an observational study." Journal of Safety Research. 37.2 (2006): 207-212.

Seo, Dong-Chul, Torabi, Mohammad R. "The Impact of In-Vehicle Cell-Phone Use on Accidents or Near-Accidents Among College Students." Journal of American College Health. 53:3 (2004): 101-107.

Smith, Robert E. and Buchholz, Laura M. "Multiple Resource Theory and Consumer Processing of Broadcast Advertisements: An Involvement Perspective.” Journal of Advertising. XX.3 (1991) : 1-7.

Strayer, David L. and Drews, Frank A. "Profiles in Driver Distraction: Effects of Cell Phone Conversations on Younger and Older Drivers." Human Factors. 46.4 (2004): 640-649. 
Strayer, David L., Drews, Frank A., and Crouch, Dennis J. "A Comparison of the Cell Phone Driver and the Drunk Driver." Human Factors. 48.2 (2006): 381-391.

Strayer, David L., Drews, Frank A., and Johnston, William A. "Cell Phone-Induced Failures of Visual Attention During Simulated Driving." Journal of Experimental Psychology: Applied. 9.1 (2003): 23-32.

“Survey Reports Many Near-Accidents Involving Cell-Phones." Insurance Advocate. 111.21 (2000): 11-13.

Szymura, Blazej and Necka, Edward. "Visual selective attention and personality: An experimental verification of three models of extraversion." Personality and Individual Differences. 24.5 (1998): 713-729.

Tornros, Jan E. B. and Bolling, Anne K. "Mobile phone use - Effects of handheld and handsfree phones on driving performance." Accident Analysis \& Prevention. 37.5 (2005): 902-909.

Wood, Chip, and Hurwitz, Joshua. "Driver Workload Management During Cell Phone Conversations." Third International Driving Symposium on Human Factors in Driving Assessment, Training, and Vehicle Design. 2003. 


\section{APPENDIX A - Consent Form \\ RESEARCH SUBJECT INFORMED CONSENT FORM \\ [Distracted Driving: Do drivers comprehend what they see while conversing on a cell phone?]}

\section{Prospective Research Subject: Read this consent form carefully and ask as many questions as you like before deciding whether you want to participate in this research study.}

I understand that I have been recruited to participate in a study examining cell phone use and driver distraction. If I consent to participate in this study, I will watch a driving video on a computer screen, identify stimuli presented on the video, and complete a series of cell phone tasks.

I understand that I must use my cell phone to participate in this experiment.

The time to complete this experiment should be approximately two and a half hours.

It is unlikely that I will directly benefit from my participation in this study, as it is merely for academic research purposes. It has been made clear to me that my information in the study records will be kept confidential, and made available only to persons conducting the experiment. Additionally, the results will be published for scientific purposes, but my name will not be referenced.

There are no predictable physical ill effects or risks associated with participating in this experiment.

I understand that I may refuse to participate in this study and am free to cease participating at any time after the study has started.

If you have concerns/questions, please contact:

Dr. Kevin Rider, WVU Assistant Professor, [deleted]

I have read and understood this consent form, and I voluntarily agree to participate in this study.

$\begin{array}{ll}\overline{\text { Participant's Name (Printed) }} & \\ \overline{\text { Participant's Signature }} & \text { Date } \\ \text { Investigator's Signature }\end{array}$

Prospective Research Subject: Read this consent form carefully and ask as many questions as you like before deciding whether you want to participate in this research study. 